CLÓVIS HENRIQUE LEITE DE SOUZA

PARTICIPAÇÃO SOCIAL NO GOVERNO LULA: UM OLHAR SOBRE O MODO PETISTA DE GOVERNAR

BRASÍLIA

2006 


\title{
PARTICIPAÇÃO SOCIAL NO GOVERNO LULA: UM OLHAR SOBRE O MODO PETISTA DE GOVERNAR
}

\author{
CLÓVIS HENRIQUE LEITE DE SOUZA
}

\author{
Monografia apresentada para a obtenção \\ do grau de bacharel em Ciência Política na \\ Universidade de Brasília. \\ Orientadora: Profa. Dra. Rebecca Abers \\ Examinadora: Profa. Dra. Lúcia Avelar \\ Examinador: Prof. Dr. Paulo Quermes
}

\section{BRASÍLIA}

Junho de 2006 


\section{Resumo}

Este trabalho insere-se no campo de estudos sobre práticas de gestão democrática. Tem como base de análise as experiências de participação social desenvolvidas no Governo Lula com foco nas Conferências Nacionais. A partir da caracterização do modo petista de governar delineado pelo Partido dos Trabalhadores com as experiências em governos municipais e estaduais, o estudo analisa as iniciativas de ampliação da participação social em nível federal com reflexos no processo de consolidação da democracia brasileira.

Palavras-chave: conferências, democracia, gestão democrática, governo Lula, participação social, Partido dos Trabalhadores. 
Dedico este trabalho às pessoas que fazem da participação social uma utopia em realização.

Agradecimentos aos meus pais por todo o amor, a Eduardo, Henrique e Mateus pelas parcerias e oportunidades de aprendizado, a professora Rebecca pela orientação, aos entrevistados pelas informações $e$ ao Grupo Interagir pelas experiências de participação e prática política. 


\section{Sumário}

Página

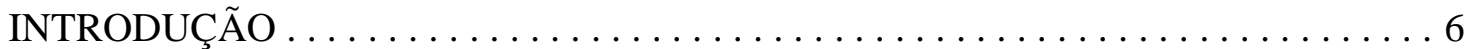

Apresentação e justificativa . . . . . . . . . . . . . . . . . 6

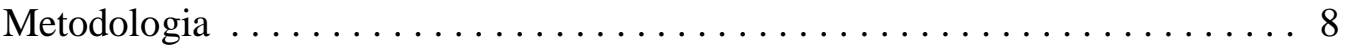

1. SURGIMENTO DO MODO PETISTA DE GOVERNAR $\ldots \ldots \ldots \ldots \ldots \ldots \ldots$

1.1. Fundação do partido: formação de identidade democrática . . . . . . . 10

1.2. Experiências de gestão: surgimento do modo petista de governar . . . . . . 12

2. BASES DA GESTÃo DEMOCRÁTICA . . . . . . . . . . . . . . . . . 16

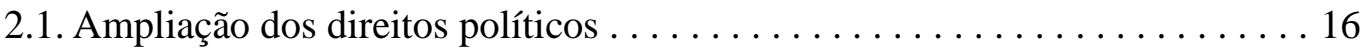

2.2. Nova cidadania . . . . . . . . . . . . . . . . . . 18

3. CARACTERIZAÇÃO DO MODO PETISTA DE GOVERNAR $\ldots \ldots \ldots \ldots \ldots \ldots$

3.1. Criação de novas esferas públicas democráticas. . . . . . . . . . 21

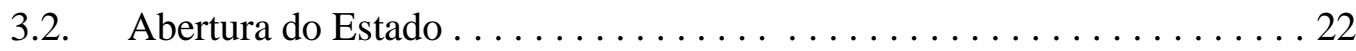

3.3. Redefinição dos atores políticos ................. 23

4. PARTICIPAÇÃO SOCIAL NO GOVERNO LULA . . . . . . . . . . . . . . 27

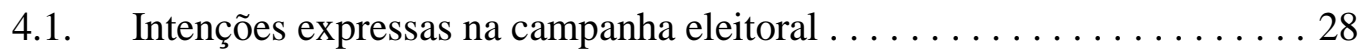

4.2. Estrutura de gestão . . . . . . . . . . . . . . . . . . . . . 29

4.3. Ações de governo .......................... 33

5. A EXPERIÊNCIA DAS CONFERÊNCIAS NACIONAIS $\ldots \ldots \ldots \ldots \ldots \ldots . \ldots 37$

5.1 Conferências Nacionais de Meio Ambiente . . . . . . . . . . . . . . . . . 39

5.1.1. Descrição . . . . . . . . . . . . . . . . . . . 39

5.1.2. Análise .......................... 42

5.2 Conferência Nacional de Cultura . . . . . . . . . . . . . . . . . . 46

5.2.1. Descrição . . . . . . . . . . . . . . . . . . . . . . . . . . 46

5.2.2. Análise . . . . . . . . . . . . . . . . . . . . . . 48

5.3. Limites e Possibilidades . . . . . . . . . . . . . . . . . . . . . . . 51

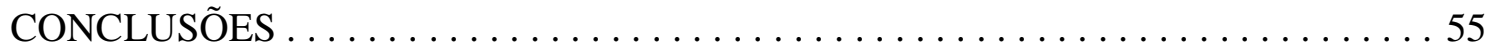

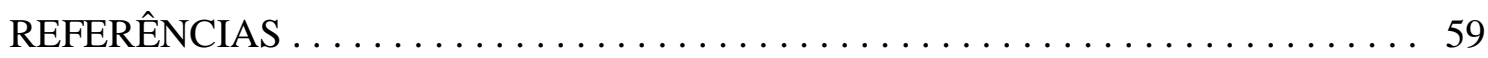




\section{INTRODUÇÃO}

\section{Apresentação e justificativa}

Vivemos em um país em que o regime democrático não tem 40 anos de existência, se incluirmos os períodos anteriores à ditadura recente. Esse fato deve ser lembrado como desafio para uma nação que pretende tornar real a concepção de democracia como governo do povo, ao enfrentar a evidente crise de representação política que abala os fundamentos do modelo democrático atual (MESQUITA JÚNIOR \& NOGUEIRA, 2005). Assim, experiências de governo que possam enraizar valores democráticos em nossa cultura política necessitam de atenção por parte da Ciência Política.

A pesquisa realizada está no âmbito das práticas de gestão democrática e propõe perspectiva diferenciada, pois o campo de estudos políticos tradicionalmente enfatiza a política institucional, com destaque para legislativo e sistema eleitoral. Tendo em vista a relevância para o processo de consolidação da democracia no país, o presente trabalho examina as iniciativas de participação social do governo Lula, com foco nas conferências nacionais, a partir da caracterização de elementos centrais das experiências de participação em gestões locais do Partido dos Trabalhadores - PT.

Os processos participativos são intrínsecos à gestão democrática, pois é a maneira como são realizadas as decisões coletivas na esfera pública que a diferencia de outras formas de governo. Não se trata de voltar aos tempos da pólis grega com um modelo ultrapassado de democracia direta, mas sim encarar as realidades das sociedades contemporâneas e inovar no sentido da orientação do Estado pela Sociedade. Assim, a criação de canais institucionais de participação que dêem conta da complexidade da sociedade brasileira é o desafio preeminente à idéia de gestão democrática. 
O PT, nascido em meio a transição democrática, destaca-se por construir sua identidade na tentativa de romper com a lógica elitista da política brasileira. Com a perspectiva de promover as mudanças de baixo para cima, enfrentou desafios internos e foi considerado uma anomalia no sistema partidário nacional pela iniciativa de manter relação direta com as bases expressa na própria estrutura interna de funcionamento (KECK, 1991). Assim, o estudo sobre a maneira como o PT realiza sua visão de gestão democrática justifica-se por ser intrínseca à vida do partido, constitutiva de sua identidade, inovadora e referência de prática de gestão capaz de influenciar outros partidos.

A participação nas instituições políticas trouxe amadurecimento e possibilitou a organização interna do PT (KECK, 1991). O PT pode, nas experiências em administrações municipais, implementar seu "projeto de governo municipal democrático e popular", no qual a participação popular era um dos traços centrais (BITTAR, 1992:22). Mesmo com as divergências internas a respeito de como tornar real a proposta de co-gestão, práticas inovadoras de gestão democrática foram implementadas (Entrevistado 2) e, internamente, a participação popular foi percebida como cultura partidária na gestão pública, o que alguns chamaram de modo petista de governar.

Havia forte expectativa que, ao assumir a Presidência da República em 2002, o PT pudesse dar continuidade à proposta de participação popular vivida nos governos locais e ampliá-la em nível federal (MAPAS, 2005:2; MORONI, 2005:3). No decorrer do mandato, ao intentar efetivar os compromissos de campanha (PT, 2002a e 2002b), o governo estruturou-se para criar e fortalecer canais institucionais de participação, em especial consultas públicas, ouvidorias, conselhos e conferências. Ressaltamos as conferências nacionais, processos de discussão em torno de grandes áreas de políticas públicas como meio ambiente, cultura, saúde etc, que envolveram milhões de pessoas em etapas municipais, estaduais e nacionais. Cabe, pois, análise sobre como as experiências de participação popular desenvolvidas pelo PT em âmbito local, cunhadas no modo petista de governar, foram aproveitadas no governo Lula.

A pesquisa é motivada pela aparente frustração à expectativa de aproveitamento das experiências locais do PT no desenvolvimento das ações de participação popular em nível nacional. Sabemos que as diferenças entre os âmbitos locais e o nacional não permitiria a 
transposição de modelos de gestão local de participação para o nível nacional. No entanto, as lições aprendidas nas práticas municipais deveriam, naturalmente, basear a concepção de participação social no governo Lula. A partir disso, a questão de pesquisa foi formulada: as experiências de participação social do PT em nível local foram incorporadas em nível federal?

\section{Metodologia}

Com o intuito de analisar como os aprendizados das gestões locais do PT influenciaram a concepção e a prática da participação social no governo Lula, o trabalho apresenta caracterização do modo petista de governar e desenvolve análise das ações de participação social do governo Lula com foco nas conferências nacionais, em específico as de Meio Ambiente e de Cultura. O objetivo aqui é constatar se as lições do âmbito local foram aproveitadas no âmbito nacional e perceber quais aspectos da gestão local petista, no que diz respeito à participação, foram adaptados e implementados no governo Lula. Não nos deteremos nas possíveis justificativas da aparente descontinuidade entre a experiência anterior e a atual.

Neste trabalho, foi desenvolvida pesquisa bibliográfica com a finalidade de caracterizar as peculiaridades das práticas de participação social empreendidas pelo PT nos governos locais. A concepção diferenciada de gestão democrática do PT está apresentada, na seção 1, a partir de sua história de fundação, estrutura interna de funcionamento, e experiências de gestão local. Para tal, foram utilizadas publicações do PT, reflexões de gestores e intelectuais petistas, além de publicações acadêmicas sobre a esquerda brasileira e o processo democrático nacional.

Esta investigação permitiu, na seção 3, a caracterização das práticas de gestão democrática expressas sob o modo petista de governar, sendo três os elementos centrais: criação de novas esferas públicas democráticas; abertura do Estado e redefinição dos atores políticos. Cada um destes, especificados em aspectos analíticos, permitiu análise detalhada das experiências de participação social do governo Lula.

$\mathrm{Na}$ seção 4, a análise foi iniciada com a explicitação dos compromissos de campanha concernentes à participação, depreendidos do plano de governo e de documento 
orientador de sua formulação. A estrutura de governo implementada para dar conta da estratégia de participação foi estudada a partir da legislação promulgada. Ademais, as ações de participação empreendidas foram descritas com base em materiais oficiais, bem como em reflexões feitas por membros da sociedade civil.

Finalizando o trabalho, a seção 5 traz olhar acurado sobre as conferências nacionais, em especial sobre as de Meio Ambiente e a de Cultura que, analisadas em separado e avaliadas comparativamente, compõem o quadro analítico da pesquisa. Esta seção baseou-se em quatro entrevistas com perguntas semi-estruturadas com coordenadores das Conferências Nacionais de Meio Ambiente e de Cultura e com assessor da Secretaria-Geral da Presidência da República, além de conversas informais com três participantes e cinco integrantes das equipes das Conferências. As informações coletadas foram complementadas com a atuação prática como integrante das equipes de desenho e desenvolvimento de metodologia e de formação de facilitadores das Conferências Nacionais de Segurança Alimentar e Nutricional, Cultura, InfantoJuvenil de Meio Ambiente e Seminário Nacional de Políticas Públicas para as Culturas Populares.

Diante da pluralidade de atores envolvidos, da diversidade e da complexidade das questões nacionais, a experiência do PT no governo federal merece atenção daqueles que se ocupam das práticas de gestão democrática. A partir da caracterização do modo petista de governar, estabelecendo três elementos de análise, este estudo concentra o foco do olhar nas iniciativas de participação social desenvolvidas no governo Lula, com mais atenção às conferências das áreas ambiental e cultural. Passemos, pois, à análise dessa experiência de gestão democrática que certamente marcará o processo de consolidação da democracia brasileira. 


\section{SURGIMENTO DO MODO PETISTA DE GOVERNAR}

Ao iniciar a caracterização do modo petista de governar, cabe um rápido sobrevôo na história do Partido dos Trabalhadores - PT para destacarmos elementos formadores de sua identidade que o diferencia de outros partidos políticos brasileiros. Como Margaret Keck afirma em sua obra referência sobre o partido, foi na tentativa de equilibrar objetivos aparentemente inconciliáveis como "reforçar a capacidade organizacional dos movimentos sociais, construir um movimento político amplo buscando uma mudança fundamental nas relações sociais, construir um partido de militantes com estruturas democráticas, funcionar no nível eleitoral, participar das instituições políticas", (KECK, 1991:268) que sua identidade política foi formada.

As divergências entre preferências ideológicas em relação ao papel das instituições representativas e sua relação com a classe trabalhadora também marcaram os anos iniciais e a formação da identidade partidária. O dilema da representação apenas de trabalhadores ou pluriclassita foi enfrentado (KECK, 1991:147), quando resultados eleitorais desfavoráveis apontaram a necessidade de rever a tática de representação exclusiva de trabalhadores para ampliação da base de sustentação do PT com a representação de outras classes.

O processo eleitoral impulsionou a organização partidária (KECK, 1991). E, a partir das vitórias crescentes em cidades médias e grandes na segunda metade da década de 80 e nos anos 90, foram empreendidas práticas de gestão que orientaram o partido e deram margem para o surgimento de alternativas específicas das administrações petistas no que diz respeito à participação social, o modo petista de governar.

\subsection{Fundação do partido: formação de identidade democrática}

O Partido dos Trabalhadores foi fundado em 1980, em meio à abertura política do regime militar. Na sua fundação, o PT uniu militantes políticos de esquerda críticos das 
tradições vanguardistas da esquerda tradicional, integrantes de comunidades eclesiais de base, intelectuais, estudantes, líderes de sindicatos e de diversos movimentos sociais (SAMUELS, 2004).

Uma das características diferenciadoras do partido era sua democracia interna (KECK, 1991) que incluia estrutura decisória descentralizada. Houve clara "preferência ideológica pela vigência de arranjos democráticos no interior da própria organização partidária" (LACERDA, 2002:49). Essa referência às decisões pelas bases já estava expressa nos documentos de fundação do PT, tanto no manifesto de lançamento como no programa (PT, 1998:65-73). O trabalho de base fundamentou a ação e a doutrina do partido, sendo institucionalizado em regulamentos internos, mas não o deixou imune à tendência de oligarquização da organização partidária.

Nesse sentido, cabe ressaltar que poucos foram os trabalhos acadêmicos que detectaram a presença de tendências oligárquicas ou vanguardistas no PT. Lacerda, mesmo reconhecendo os traços de democracia interna, não deixa de apontar a propensão centralizadora: “O PT, portanto, não é imune aos efeitos de sua transformação em uma grande 'máquina' dirigida à competição eleitoral de massas com o conseqüente fortalecimento dos líderes em relação à base." (LACERDA, 2002:52).

Outra característica marcante são as divergências entre grupos internos, o que em certos momentos abalou a unidade partidária. "A formação de facções para a competição pelo voto dos filiados petistas não só é permitida como regulamentada." (LACERDA, 2002:49-50). Esse elemento é fundante na cultura partidária por contribuir para a formação de uma identidade democrática. Lacerda, ao analisar as diversas tendências que disputaram a direção partidária entre 1993 e 1999, percebe que as discordâncias entre os grupos relacionam-se "ao papel das instituições representativas na persecução do objetivo socialista quanto à política de alianças" (LACERDA, 2002:71).

A identidade democrática, vinculada à estrutura interna e à relação do partido com movimentos sociais, parece agregar as tendências da configuração ideológica interna em torno da democracia como valor estratégico. As posições internas à "direita" e à "esquerda" 
valorizam as formas de democracia direta e acreditam que devem ser aperfeiçoadas (LACERDA, 2002:57), embora divirjam nas práticas democráticas. Cabe lembrar que Lacerda trabalha com dados da segunda década do partido, ou seja, após as primeiras experiências como governo em municípios e estados. Não contempla, pois, os acontecimentos recentes quando a ética e a descentralização das decisões foram postas à prova. No entanto, os elementos caracterizadores da cultura partidária - estrutura decisória descentralizada, regulamentação das disputas internas e relação direta com movimentos sociais - influenciaram as práticas administrativas desde as primeiras experiências de gestão local.

\subsection{Experiências de gestão: surgimento do modo petista de governar}

Foi ainda nos anos 80 que o PT iniciou experiências de governo local. Embora a ampliação da representação petista tenha crescido a partir das eleições municipais de 1988, em 1982 foram eleitas em Diadema - SP e Santa Quitéria - MA as primeiras prefeituras geridas pelo PT (TREVAS, 1999:51).

Nas administrações do PT nos anos 80, destacando Fortaleza - CE e Vila Velha - ES, por serem cidades maiores e com prefeituras eleitas no segundo período da década - 1985, a necessidade de transformar a utopia da participação popular em planos de ação concreta ganhou força nos debates acerca dos conselhos populares (AZEVEDO, 1988).

Florestan Fernandes já havia identificado as diferentes tendências que marcavam as várias ideologias de esquerda presentes no PT no que diz respeito à participação social. Referindo-se aos conselhos, disse tratar-se "da melhor maneira de administrar o sistema de poder municipal, sob condições reais de participação popular."(FERNANDES, 1988). O dilema enfrentado à época dizia respeito ao caráter consultivo ou deliberativo dos conselhos.

No projeto político do partido, a participação tem grande importância diante do firme propósito de transformar relações de poder estabelecidas na sociedade brasileira (BITTAR, 1992: 11 e 211). Porém, em 1989, quando o PT assumiu 36 prefeituras, sendo 21 em cidades de até 50 mil habitantes, 4 em cidades acima de 50 mil habitantes, 2 em cidades acima de 100 mil habitantes e 9 em cidades com mais de 200 mil habitantes, incluindo três capitais - São Paulo - 
SP , Vitória - ES e Porto Alegre - RS, (TREVAS, 1999: 246) a inexperiência administrativa era explícita (BITTAR, 1992: 17) e o "distanciamento entre o acúmulo de reflexão e a prática já pode ser percebido" (PONTUAL \& SILVA, 1999:62).

"Naquele momento, havia no PT uma concepção de participação fortemente baseada nos conselhos populares." (PONTUAL \& SILVA, 1999:62). Isso é notório se observamos os escritos de 1988 publicados na revista Teoria \& Debate, publicação do PT. O primeiro a escrever foi Celso Daniel, com o artigo Como viabilizar a participação popular no governo municipal. O autor falava das desvantagens do caráter deliberativo, do conflito autonomia de movimentos e institucionalização dos conselhos. Também apontava para a possibilidade do controle do orçamento por parte da população (DANIEL, 1988).

O segundo artigo foi de Valeska Peres Pinto em que explicita as experiências da prefeitura de Diadema e já traz a visão de uma forma diferenciada de prática administrativa afirmando que "A participação popular deve ser parte integrante da ação administrativa". (PINTO, 1988) No último número da revista no ano de 88, Ricardo de Azevedo expõe a prevalência dos conselhos: "Concretamente, os conselhos hoje são espaços democráticos de atuação que a prefeitura abre no sentido de que haja participação da população, de forma crescente, na definição de tudo aquilo que lhe diz respeito.” (AZEVEDO, 1988).

Os conselhos populares eram uma proposta de democratização do poder local já experienciada em Diadema a partir de 1982. Com inspiração na comuna de Paris, nos conselhos de fábrica e na doutrina dos sovietes, parte dos petistas tinham a expectativa de "criar organismos de base com vistas a uma futura sociedade socialista" (SIMÕES, 1992:138). As disputas internas ao partido, além do caráter deliberativo ou consultivo, também variavam a respeito da constituição dos conselhos. Para alguns, os conselhos deveriam se constituir a partir dos núcleos de base do PT e "estariam abertos somente à participação dos 'trabalhadores' e demais camadas 'exploradas"' (idem). Para outros, os conselhos deveriam se constituir a partir de assembléias de bairro, com o maior número possível de participantes, independente da filiação partidária, na visão pluriclassista. 
Maria da Glória M. Gohn, ao estudar as experiências de conselhos populares nas administrações petistas da década de 80, captou as principais questões que permeavam o debate interno do PT no que diz respeito aos conselhos populares: definição do papel, caráter e objetivos; delimitação da competência e atribuições; forma de organização e composição. Alguns petistas viam os conselhos como "instrumentos para viabilizar propostas e projetos mais abrangentes, que apontem para uma nova sociedade" (GOHN, 1990:83). Para outros, os conselhos eram formas de "transformação da administração pública" (idem).

As experiências administrativas deram força ao debate acerca de quem cria os conselhos, quem deles participa e com qual poder efetivo (GOHN, 1990). Essas indagações a respeito dos conselhos foram transportadas a outras formas de participação popular e as respostas nas ações foram delineando o modo petista de governar.

Foi com a experiência concreta de ser governo que o Partido dos Trabalhadores delineou o modo petista de governar e renovou o olhar a respeito da participação popular (PONTUAL \& SILVA, 1999:62). Como já foi dito, na primeira onda de gestões do PT foram eleitas 36 prefeituras, em 1992 foram 54, em 1996 o aumento foi de 106\%, com 115 prefeituras eleitas. Em 2000, 187 prefeitos petistas assumiram, sendo $127 \mathrm{em}$ cidades de até 50 mil habitantes, 14 em cidades acima de 50 mil habitantes, 17 em cidades acima de 100 mil habitantes e 29 em cidades com mais de 200 mil habitantes (SNAI, 2002). Por fim, em 2004, já com o impulso da eleição de Lula em 2002, foram eleitas 411 prefeituras petistas - aumento de $120 \%$ em relação a 1998 - sendo 9 capitais (CREMONESE, 2004).

Cabe aqui apenas menção à trajetória nas eleições de governos estaduais, pois o olhar é para as gestões municipais dada a dimensão e a variedade de experiências que cunharam o modo petista de governar. Em 1994, foram eleitos Cristóvam Buarque no Distrito Federal e Vitor Buaiz no Espírito Santo. Em 1998, Jorge Viana no Acre, Zeca do PT no Mato Grosso do Sul e Olívio Dutra no Rio Grande do Sul. Em 2002, o PT manteve o número de governos estaduais reelegendo Jorge Viana e Zeca do PT e elegendo Wellington Dias no Piaúi (SNAI, 2002).

Os petistas afirmam que o modo petista de governar vai além de uma marca fantasia, caracterizando-o como alternativa de governo (TREVAS, 1999:55). E como eixos 
centrais desse projeto apontam a inversão de prioridades, a desprivatização do Estado e a participação popular (BITTAR, 1992:22). Nos interessa neste trabalho o eixo participação popular que acaba por colaborar com o aspecto da transformação do estatal em público, intenção do eixo desprivatização do Estado.

Após esta breve descrição da formação da identidade democrática do partido, bem como a percepção de que foi na prática de gestões locais que o modo petista de governar surgiu, podemos sintetizá-lo como concepção de gestão democrática em que há um processo de criação de novas esferas públicas visando a efetivação da participação popular. Antes de prosseguirmos na caracterização das práticas concernentes a essa proposta, cabe delinear as bases dessa concepção de gestão: ampliação dos direitos políticos e nova cidadania. 


\section{BASES DA GESTÃO DEMOCRÁTICA}

Com a prática administrativa, o PT desenvolveu uma maneira de gerir a coisa pública que buscou incorporar a população nos processos decisórios. Para romper com a lógica da política como terreno apenas de especialistas, embora não houvessem definições determinantes à maneira de ação, o modo petista de governar teve como subsídio algumas idéias que serão expostas nesta seção.

É com o reconhecimento de que no Brasil há necessidade de "administrações públicas abertas, democráticas, voltadas para as reivindicações populares” (GOHN, 1990:82) que surge a necessidade de implementar modelos de gestão democrática. No Partido dos Trabalhadores, a democracia emerge como valor substantivo caracterizando de maneira singular suas administrações. Valor, como vimos, que nasce na forma de organização partidária e se pratica nos governos. Não existem grandes teorias ou orientações unificadas para as práticas de participação que consubstanciam a concepção de gestão democrática (Entrevistado 2; Entrevistado 3).

A gestão democrática do PT se fez tentando garantir os meios para a participação popular (PINTO, 1988) nos negócios públicos, ampliando a perspectiva dos direitos políticos e proporcionando a emergência de uma nova cidadania. Como parte da cultura partidária foi transposta para a forma de governar, não só as virtudes sobrevieram, mas também os vícios. Um exemplo é a indefinição de como realizar a gestão democrática. Concentremo-nos, por hora, nas perspectivas que podemos observar como basilares à relação Estado-Sociedade que o PT procura empreender em suas experiências como governo.

\subsection{Ampliação dos direitos políticos}

"Sabemos, e seguramente todos concordamos, que voto e eleição são requisitos necessários e indispensáveis a qualquer regime democrático. Nem um nem outra, contudo, são 
sinônimos de democracia.” (MESQUITA JÚNIOR \& NOGUEIRA, 2005:13) Como lembram Mesquita e Nogueira, o sufrágio é um requisito necessário, mas não suficiente aos regimes democráticos. Nesses regimes, a cidadania se realiza quando os valores democráticos se concretrizam na ampliação e no exercício dos direitos políticos, sendo esses além-sufrágio, e a participação, não limitada ao voto.

Já no debate de implementação dos Conselhos Populares, essa visão era explícita para o Partido dos Trabalhadores. Podemos notar que Bittar, ao caracterizar a concepção de gestão democrática do partido, disse que o modo petista de governar se afirma "pela instituição do direito à participação, combinando elementos da democracia representativa aos da democracia participativa, aprofundando as formas de controle da sociedade sobre as prefeituras petistas, por ocasião do orçamento municipal através dos conselhos, audiências públicas e plenárias nos bairros.” (BITTAR, 1992:25 - grifo nosso).

Com o intuito de efetivar os princípios democráticos nas gestões municipais, o PT percebe a ampliação dos direitos políticos por meio da efetivação do direito à participação como possibilidade efetiva de "partilha do poder e de intervenção direta na formulação das políticas municipais" (BITTAR, 1992:216). Os espaços de participação, intrínsecos à gestão democrática, ampliam a esfera de interação entre as pessoas e permitem a realização da política em práticas democráticas. À luz da participação como não limitada aos procedimentos formais da competição eleitoral (BITTAR, 1992:210).

A ampliação dos direitos políticos como base do modo petista de governar requer a participação constante no governo, a intervenção nas questões públicas de forma continuada e a transparência nas ações governamentais permitindo o controle social (BITTAR, 1992). Assim, há necessidade de viabilização de mecanismos institucionais específicos a cada situação, que possibilitem a manifestação dos cidadãos, a recepção, por parte dos governantes, dos anseios populares, bem como a fiscalização das ações governamentais (Entrevistado 2).

Esses mecanismos advirão de uma reestruturação estatal (GOHN, 1990), que permita a reorientação da relação Estado-Sociedade. A combinação da democracia direta com a 
democracia representativa constitui uma maneira de ampliar a co-responsabilidade pelo destino comum incentivando uma nova cidadania.

\subsection{Nova cidadania}

A nova cidadania se configura como elemento estruturante da gestão democrática pela necessidade de "ampliação e redefinição dos direitos de cidadania como base da administração pública" para se efetivar a participação popular (BITTAR, 1992:217). Participação esta que possibilite uma relação democrática e eficiente entre a Sociedade e o Estado.

O Partido dos Trabalhadores, ao analisar aspectos da cultura política brasileira, reconhece a necessidade de transformação de práticas sociais impeditivas desse padrão de relacionamento Estado-Sociedade que comprometem a realização da gestão democrática:

"Sob o ângulo da nossa cultura política, a presença, no âmbito privado, da força das relações familiares e de amizade - uma das marcas da cultura nacional -, tem sido historicamente metamorfoseada, no âmbito público, em relações patrimonialistas, clientelistas, na tendência à conciliação. Tratam-se de elementos de privatização do público, de formas de compensação social "privadas" que contribuem para legitimar as inaceitáveis desigualdades do país, produzindo uma atrofia da esfera pública democrática, espaço por excelência de luta por direitos de cidadania. Tais características de nossa cultura política - convém lembrar - são alimentadas pela presença de relações formalmente democráticas. Daí, pois, o ressurgimento com vigor do clientelismo no momento da redemocratização, isto é, em paralelo ao avanço das lutas e conquistas sociais na década de 1980." (PT, 2002a:5)

A idéia de nova cidadania como base da gestão democrática advogada pelo modo petista de governar requer a constituição de sujeitos sociais ativos. A ampliação do conceito da cidadania é decorrência dessa visão, pois seu significado e importância não se esgotam na aquisição formal-legal de um conjunto de direitos. "A cidadania se cria com uma presença ativa, crítica, decidida, de todos nós com relação à coisa pública.” (FREIRE, 1994:74)

A professora Evelina Dagnino, ao estudar a transformação das práticas da esquerda brasileira no que diz respeito à cidadania, afirma que só a noção de cidadania ativa torna operacional a democratização e a ruptura com padrões comportamentais personalistas-autoritários (DAGNINO, 1998:82-83). "O modo petista de governar procura construir esta nova cidadania 
nas articulações entre o Estado e a sociedade civil, aprofundando a democracia e ampliando o espaço para a participação popular.” (BITTAR, 1992:211)

A implementação da gestão democrática baseia-se, como visto, na ampliação de direitos políticos e na nova cidadania. Elementos que permitem a ruptura com padrões da cultura política tradicional brasileira e a formação de postura crítica frente à coisa pública. Tendo em vista o surgimento da identidade política do PT, na forma de organização interna e nas práticas em governos locais, e a descrição das bases de sua concepção de gestão democrática, passamos agora à caracterização do modo petista de governar. 


\section{CARACTERIZAÇÃO DO MODO PETISTA DE GOVERNAR}

O modo petista de governar, no que diz respeito à participação, se fundamenta na partilha do poder de decisão entre Estado e Sociedade, (Entrevistada 4) sendo que o poder "deixa de se concentrar nas mãos do governo, passando a ser dividido com a comunidade" (DANIEL, 1999:232). Isso implica na ruptura com "o modo tradicional de se fazer política em nossa sociedade" (BITTAR, 1992:209).

Essa mudança é sentida nos discursos e nas práticas das esquerdas latinoamericanas durante o processo de democratização. Afastando-se das tendências autoritárias da esquerda tradicional, o Partido dos Trabalhadores (PT) apresenta singularidades derivadas "em parte de sua tentativa, no interior do processo de transição, de criar uma identidade política que rompia ao mesmo tempo com o padrão de relações que caracterizavam o período autoritário e com tradições históricas" (KECK, 1991:52).

Foi na transição democrática que essa postura da esquerda se alterou e deu margem a novas percepções das práticas políticas. Esse processo implicou "mudanças na percepção geral sobre o significado da própria política: onde, como, por quem e sobre o que a política deve ser feita”. (DAGNINO, 1998:78 - grifo nosso).

Nesse sentido, o PT, por ser um partido de massas que congregou boa parte do pensamento da esquerda brasileira durante os anos 80 e 90, (LACERDA, 2002:48) constituiu práticas de gestão democrática resignificantes da política. A resignificação da política apontada por Dagnino nos oferece os elementos caracterizadores do modo petista de governar: criação de novas esferas públicas democráticas (onde); abertura do Estado (como) e redefinição dos atores políticos (por quem). Não utilizamos na análise o fator conteúdo (sobre o que) por não considerarmos diferenciadora da proposta de gestão democrática aqui em análise. 


\subsection{Criação de novas esferas públicas democráticas}

O primeiro elemento do modo petista de governar diz respeito ao local do fazer político. A criação de novas esferas públicas democráticas vocacionadas à integração entre Sociedade e Estado (DANIEL, 1999:232) envolve gestão democrática, ou co-gestão, a partir de aspectos como auto-regulação, abertura para explicitação de interesses e conflitos, e interação entre Estado e Sociedade para discussão e negociação de políticas públicas.

A institucionalização de canais de participação auto-regulados (SOUZA, 1999:74) é uma visão e prática fundamental para o estabelecimento de esferas públicas democráticas. A institucionalização de mecanismos de participação "deve acompanhar a realidade social, tem que ser algo demandado e desejado pela sociedade" (SOLER, 1994:61). Cada experiência de participação é única pela realidade sócio-política singular em que se estabelece. Porém, a visão de auto-regulação é comum nas ações para a criação de novas esferas públicas democráticas.

Podemos observar nas ações dos governos petistas processos em que os espaços de fazer política são ampliados, ampliando a esfera pública e aproximando a Sociedade do Estado. Nos conselhos setoriais, nos conselhos de gestão, nos orçamentos participativos, nas assembléias populares, nos fóruns setoriais autônomos, nos debates sobre planos diretores, nas sub-prefeituras e noutras experiências, percebe-se a diversidade de espaços e canais de participação impulsionados com a finalidade de interlocução entre o Estado e os diversos segmentos da sociedade (PONTUAL \& SILVA, 1999).

Com a criação de espaços e canais de participação a continuidade do processo é questão preeminente. No entanto, a formalização em leis não é garantia de continuidade.

"Seria ilusório imaginar que a mera formalização em lei dos espaços e processos participativos - ainda mais num país cujo costume é criar uma profusão de leis que depois não se incorporam à prática social, tornando-se letra morta - e até mesmo a força da população organizada pudessem obrigar um governo contrário ao princípio da participação popular a assumi-la como parte de seu método de gestão." (DANIEL, 1999:234)

A continuidade dos processos de participação e a manutenção de esferas públicas criadas por governos petistas não se sustentam em legislações, embora alguns gestores acreditem nessa garantia (Entrevistado 1). A perspectiva de continuidade dos novos espaços de 
participação se fundamenta no componente da auto-regulação e na capacidade dos governos de tornarem o Estado um instrumento de democracia.

"Os canais institucionais de participação, como espaço de discussão e de negociação de políticas públicas, são espaços de explicitação de conflitos e interesses." É inerente à criação de novas esferas públicas democráticas o surgimento de conflitos e, nesse sentido, deve-se garantir a autonomia e o direito de pressão dos cidadãos, organizados em movimentos ou não, bem como a auto-regulação na construção de regras democráticas para os processos participativos (PONTUAL \& SILVA, 1999:64). Trata-se de fomentar espaços públicos para a “administração de conflitos a partir da sociedade e não apenas a partir do Estado" (GOHN, 1990:84).

\subsection{Abertura do Estado}

Cabe, pois, ao Estado adotar uma postura que permita o aprofundamento do controle social e a descentralização da gestão. Esse é o segundo elemento caracterizador do modo petista de governar: a abertura do Estado. É uma forma peculiar de se fazer política em que a relação Estado-Sociedade se fortalece na medida em que há disposição de ruptura com a racionalidade burocrática e verticalizada do Estado (BITTAR, 1992:220), transparência, e de incorporação da concepção de gestão democrática às práticas administrativas.

"Sem a soberania popular exercida no dia-a-dia, mediante a participação individual e coletiva dos cidadãos, o Estado tende a se reproduzir como aparelho manipulado e privatizado em detrimento do interesse público e da maioria da população.” (BITTAR, 1992:210) Fala-se aqui da partilha real de poder com a população como meio de resgate da função pública do Estado, pois, com o controle social efetivo, a cultura patrimonialista é minimizada.

A transparência é questão central e condição para que o controle social se realize. Ao Estado cabe implementar práticas político-administrativas que permitam ao cidadão comum entender e controlar as decisões (SOUZA, 1999:76). A máquina administrativa não deve ser obstáculo e sim instrumento para a construção do poder popular (RODRIGUES, 1999:31). O papel do Estado nessa abertura é maximizar os mecanismos que permitam o aprofundamento do controle social da gestão. 
Segundo Tarso Genro, as experiências de ampliação da participação pretendem “tensionar e eliminar as barreiras burocráticas que separam o Estado e a sociedade."(GENRO, 1995:166). A visão é de abertura tal que os cidadãos entendam os processos de gestão ao ponto de “as pessoas ocuparem o Estado" (GENRO, 1995:173).

Na abertura do Estado, o papel do funcionalismo público é primordial, pois além de "agentes das políticas de governo, são acima de tudo atores do processo de democratização e resgate da coisa pública por uma nova cidadania" (BITTAR, 1992:220). Por meio de reciclagem técnico profissional e de trabalho político de esclarecimento e persuasão, o funcionalismo deve incorporar às práticas cotidianas posturas coerentes com a concepção de gestão democrática (BITTAR, 1992:219). Desta forma, esse modelo de gestão implica "substituição de procedimentos e de mecanismos" para que a participação seja assimilada e praticada de forma permanente (SOLER, 1994:61).

\subsection{Redefinição dos atores políticos}

Por fim, temos a redefinição dos atores políticos como elemento caracterizador do modo petista de governar. Na promoção da participação devem ser garantidos: o reconhecimento da pluralidade de atores políticos, o fortalecimento autônomo da sociedade organizada, a existência de espaço para população não-organizada e a legitimação do governo como ator no processo de negociação de políticas públicas.

Quem faz a política? Como já apontado, o início das práticas dos governos petistas limitava a participação no governo a certo setores da sociedade organizada. No entanto, com as experiências acumuladas, veio o reconhecimento da pluralidade dos atores e das temáticas envolvidas nas questões políticas em decorrência da criação de novas esferas públicas democráticas.

Pontual e Silva chegam a propor a alteração do conceito de participação popular, que se baseava apenas nos movimentos populares, para participação cidadã, por ser uma concepção que dá conta da pluralidade de atores envolvidos nos processos participativos. Os autores dizem:

"É importante registrar que, ao afirmar a idéia de participação cidadã como certa superação de participação popular, não estamos negando a importância do papel 
dos movimentos sociais nos processos de participação, apenas sublinhando que esse papel não deve obscurecer a necessária abertura de oportunidade a qualquer cidadão ou cidadã que queira por decisão voluntária participar. Pensando justamente no papel fundamental dos movimentos sociais nos processos participativos, é importante, no exercício do governo, estimularmos condições para a sua qualificação e organização autônoma." (PONTUAL \& SILVA, 1999:68)

Neste trecho percebemos o duplo desafio ao propor a redefinição dos atores políticos: incluir a população não-organizada e criar condições para o fortalecimento autônomo da sociedade organizada.

Na gestão democrática que busca a emergência de uma nova cidadania o papel do Estado é redefinido quando promove a própria abertura para a co-gestão e, principalmente, com a atuação como catalizador da participação (BITTAR, 1992:220). O modo petista de governar, ao deparar-se com a inexperiência em lidar com a população não-organizada, propõe uma "visão político-pedagógica processual” (BITTAR, 1992:217) que, na criação de novos espaços de participação, reconhece o direito de participar também aos cidadãos e cidadãs que não estão filiados a partidos políticos ou associados a movimentos sociais.

Ademais, a autonomização e o fortalecimento dos movimentos sociais é uma preocupação dos governos petistas, pois quando a sociedade organizada foi convocada aos canais institucionais de participação demonstraram as "virtudes e fragilidades existentes em sua organização" (BITTAR, 1992:212). A fragmentação de demandas e a cultura política corporativista presentes na relação com a sociedade organizada, são as principais questões enfrentadas na criação de espaços de participação (BITTAR, 1992:217-221).

A simples abertura à interação nos canais de participação, que traz para a esfera pública a diversidade de atores políticos presentes na sociedade, promove o intercâmbio e o fortalecimento dos movimentos sociais. Na relação com a sociedade organizada, o Estado, para não comprometer a autonomia da mesma, deve ter atenção tanto para não impor padrões de participação que promovam a subordinação da Sociedade quanto para não desmobilizar movimentos com a incorporação de quadros qualificados ao governo (BITTAR, 1992:213). Essa é uma prática comum ao PT, até pela ligação histórica com movimentos sociais. Além da incorporação de quadros, percebe-se uma diminuição da atividade reivindicatória quando governos com bases populares assumem o poder. 
A respeito da relação dos movimentos sociais com um governo popular, as pesquisas de Teixeira e Tatagiba são esclarecedoras. Dizem as autoras:

"talvez possamos compreender a afirmação de alguns entrevistados de que quando está no poder um governo comprometido com as lutas populares 'o povo fica mais apático'. Por um lado, porque assume em relação ao governo uma responsabilidade histórica que limita um discurso mais crítico; e, por outro, porque no comando de pastas importantes, principalmente na área social, é possível encontrar antigos militantes, o que facilita o encaminhamento das demandas, já que há uma maior permeabilidade dos agentes estatais às demandas dos grupos excluídos." (TEIXEIRA \& TATAGIBA, 2005:102)

A relação Estado-Sociedade se compromete exigindo respostas a questões preeminentes. Embora os desafios dos movimentos sociais contemporâneos não sejam o foco deste trabalho, é válido expressar aqui as reflexões propostas na pesquisa referida, por traduzirem os desafios do modo petista de governar no momento de redefinição dos atores políticos.

"Se a autonomia é um valor, e acreditamos que seja, como superar os constrangimentos atuais para o seu exercício? Como avançar na definição de parâmetros não subordinados na relação com o Estado? Como os movimentos sociais podem contribuir para uma reforma democrática do Estado e das instituições por meio de uma participação na qual apareçam como agentes e não como instrumentos de legitimação de políticas e processos? Quais vínculos entre movimentos e sistema político favoreceriam a luta dos movimentos? Até onde uma participação pragmática, instrumental - que parece indicar a falta de projeto de mudança que oriente a ações dos movimentos - dificulta uma agenda de interrelação focada na autonomia?" (TEIXEIRA \& TATAGIBA, 2005:106)

Finalizando a exposição sobre os novos atores políticos reconhecidos pelo modo petista de governar, cabe falar que a partilha do poder também foi uma evolução do pensamento petista que inicialmente tinha como pretensão a "delegação de poder absoluto à comunidade". Foi a partir do "choque com a realidade" que surgiu espaço para a "compreensão sobre a necessidade e a legitimidade de o governo se fazer presente nos processos participativos, travando a disputa em torno dos seus próprios projetos, possibilitando, assim, a construção de uma síntese entre seus interesses e os interesses dos setores que participavam dos canais abertos" (PONTUAL \& SILVA, 1999:63).

O reconhecimento do governo como ator político legítimo foi um avanço no modo petista de governar, porém pressupõe que a abertura do Estado se efetive de maneira plena e que haja reconhecimento das desigualdades na interação entre Estado e Sociedade. Desta forma, 
podem ser criadas possibilidades reais de partilha do poder, intervenção na formulação de políticas públicas (BITTAR, 1992:216) e concretização da nova cidadania.

Como vimos, Dagnino provoca a resignificação da política com os elementos: onde, como e por quem a política deve ser feita (DAGNINO, 1998:78). E assim, caracterizamos o modo petista de governar, em que a política é feita em novas esferas públicas democráticas, com a abertura do Estado e por novos atores políticos. Nas próximas seções do trabalho analisaremos as propostas e práticas de participação do governo Lula com base nesses elementos. 


\section{PARTICIPAÇÃO SOCIAL NO GOVERNO LULA}

“A ascensão do Partido dos Trabalhadores à Presidência da República despertou expectativas de renovação política e de abertura à participação em movimentos sociais e organizações da sociedade civil.” (MAPAS, 2005:2) A expectativa era que o PT tivesse grande influência no governo, mesmo que as alianças para a campanha houvessem contemplado diversas correntes ideológicas e posicionamentos políticos. Desta forma, esperava-se que as práticas de participação, aqui caracterizadas pelo modo petista de governar, pudessem ser empreendidas com eficácia também em nível federal.

A participação como marca do governo federal petista foi desafiada com a complexidade do âmbito nacional e com a política do governo de coalizão que acabou por provocar impasses. O relatório do Projeto Mapas, iniciativa da sociedade civil para monitorar ações de participação social do governo Lula, acabou por constatar:

"A expectativa de fortalecimento e de generalização da participação social não se cumpriu. Embora tenham ocorrido avanços, o modelo dos conselhos, por exemplo, esbarrou em dificuldades, como a exclusão dos setores chaves das políticas públicas (as decisões sobre taxas de juros, metas de inflação, superávit primário, etc.) e a sub-representação de ativistas de movimentos sociais, em favor dos(as) empresários(as), banqueiros(as) e sindicalistas." (MAPAS, 2005:2)

A expectativa de ampliação da participação parece frustrada, embora muitos possam ser os elementos explicativos para os limites da implementação, em nível federal, do modo petista de governar. As principais ações para ampliação da participação social empreendidas no governo Lula serão descritas, a partir das intenções expressas na campanha eleitoral e da estrutura estabelecida para gestão do processo, para posterior análise específica do caso das Conferências com os elementos caracterizadores do modo petista de governar. 


\subsection{Intenções expressas na campanha eleitoral}

No Plano de Governo elaborado para a eleição de 2002 a participação popular não recebeu atenção específica. A menção à necessidade de ampliar a participação social permeia diversos temas no plano (PT, 2002b), mas no documento de concepções e diretrizes que orientaram a formulação do plano de governo foram expressas nuances específicas. $\mathrm{O}$ documento foi estruturado em três eixos que conformariam um modelo alternativo de desenvolvimento, são eles: o social, o democrático e o nacional (PT, 2002a).

As menções à participação popular e ao controle social do poder público por meio da efetivação de valores democráticos na gestão vão da política social, passando pela externa, até a econômica. É no eixo democrático que vemos referências específicas que poderiam caracterizar a intenção de um modo petista de governar em nível federal: “A gestão pública participativa - uma das referências centrais de nossos governos estaduais e municipais - deve ser uma dimensão básica da reformulação da relação entre o Estado brasileiro e a sociedade, também no nível central.” (PT, 2002a:18)

Ressaltando que a implementação dos canais de participação dependeria não só do governo, mas também da interação com a sociedade o documento destaca iniciativas relevantes no campo da participação, declaradas como intenções de governo:

\footnotetext{
"a implementação do orçamento participativo no nível central será desafio de peso, na medida em que não se trata de efetuar uma mera transposição mecânica de políticas em curso nos níveis local e estadual para o central, que é muito mais complexo (será necessário, por exemplo, tomar na devida conta a estrutura federativa brasileira); os variados conselhos temáticos ou setoriais - inclusive para o controle público das empresas estatais e das concessionárias de serviços públicos; a reformulação de fundo das agências nacionais de regulação, integrando representantes dos consumidores; instituiç̃̃es como as câmaras setoriais, voltadas à elaboração, negociação e implementação de políticas industriais ou setoriais; gestão participativa dos fundos públicos etc." (PT, 2002a:19)
}

No decorrer da campanha eleitoral de 2002, a necessidade de firmar compromissos de continuidade da gestão anterior afastando os fantasmas de desestabilização econômica e política, levaram o PT a redigir a 'Carta ao povo brasileiro'. Esse documento, 
firmado pelo então candidato Lula e intensamente divulgado, afirmava que o modelo alternativo de desenvolvimento "não poderá ser produto de decisões unilaterais do governo, tal como ocorre hoje, nem será implementado por decreto, de modo voluntarista. Será fruto de uma ampla negociação nacional, que deve conduzir a uma autêntica aliança pelo país, a um novo contrato social, capaz de assegurar o crescimento com estabilidade.” (PT, 2002c).

A preocupação era com a estabilidade, sendo que o partido assumia o compromisso com a negociação: "o PT está disposto a dialogar com todos os segmentos da sociedade e com o próprio governo" (PT, 2002c). No campo das intenções, as perspectivas para a participação social no governo expressas no decorrer da campanha eleitoral ficaram pouco claras como demonstram os documentos analisados. Estas não são específicas no sentido de dizer como, o que também não foi exigido pelo debate eleitoral brasileiro exigiu. Sendo assim, Lula foi eleito no segundo turno com o desafio de concretizar o modo petista de governar em nível federal.

\subsection{Estrutura de gestão}

Ao assumir o governo, foram delineadas estruturas para a gestão democrática do modo petista de governar em nível federal. Descrevemos aqui a distribuição de funções entre órgãos de assessoramento da Presidência no que diz respeito a articulação com atores políticos e a assuntos relevantes à participação no decorrer do governo Lula.

A Lei $n^{\circ} 10.683$, de 28 de maio de 2003, é a referência para a estruturação da Presidência da República sendo que foi alterada por medida provisória (MP 259) e leis subseqüentes (10869/04 e 11204/05) por ocasião de reformas ministeriais. Dispôs inicialmente sobre a organização da Presidência da República definindo os órgãos constitutivos: Casa Civil, Secretaria-Geral, Secretaria de Comunicação de Governo e Gestão Estratégica, Gabinete Pessoal e Gabinete de Segurança Institucional (art $\left.1^{\circ}\right)$.

A definição de competências da Secretaria-Geral foi feita pelo art $3^{\circ}$, no que diz respeito ao item de nosso interesse, não sofreu alterações subseqüentes. Diz o artigo: "À Secretaria-Geral da Presidência da República compete assistir direta e imediatamente ao Presidente da República no desempenho de suas atribuições, especialmente: I - no 
relacionamento e articulação com as entidades da sociedade civil e na criação e implementação de instrumentos de consulta e participação popular de interesse do Poder Executivo;". À Casa Civil coube a responsabilidade pela coordenação e integração das ações do Governo, pela coordenação política do Governo, pelo relacionamento com o Congresso Nacional e os partidos políticos e pela interlocução com os Estados, o Distrito Federal e os Municípios (art $2^{\circ}$ da lei 10683/03).

A lei 10869 de 13 de maio de 2004 trouxe nova redação ao artigo 1: "A Presidência da República é constituída, essencialmente, pela Casa Civil, pela Secretaria-Geral, pela Secretaria de Comunicação de Governo e Gestão Estratégica, pela Secretaria de Coordenação Política e Assuntos Institucionais, pelo Gabinete Pessoal e pelo Gabinete de Segurança Institucional." Esta lei criou a Secretaria de Coordenação Política e Assuntos Institucionais transferindo a competência da Casa Civil para a nova secretaria no que diz respeito à coordenação política do Governo, à condução do relacionamento do Governo com o Congresso Nacional e os Partidos Políticos e à interlocução com os Estados, o Distrito Federal e os Municípios (art $2^{\circ}$ da lei 10683/03 alterado pela lei 10869/04).

Na lei 11204, publicada em 5 de dezembro de 2005, a antiga Secretaria de Coordenação Política e Assuntos Institucionais tornou-se Secretaria de Relações Institucionais com competência expressa pelo artigo 2-A da lei 10869/04, incluído pela lei 11204/05: coordenação política do Governo; condução do relacionamento do Governo com o Congresso Nacional e os Partidos Políticos; e interlocução com os Estados, o Distrito Federal e os Municípios. O parágrafo $1^{\circ}$ deste artigo agregou a competência de coordenar e secretariar o funcionamento do Conselho de Desenvolvimento Econômico e Social. Interessante notar que o referido parágrafo traz a finalidade do Conselho ao falar da competência atribuída: "visando à articulação da sociedade civil organizada para a consecução de modelo de desenvolvimento configurador de novo e amplo contrato social.".

Foi esta lei que transferiu as competências "da Secretaria-Geral da Presidência da República, relativas à coordenação política do Governo, ao relacionamento com o Congresso Nacional, à interlocução com os Estados, o Distrito Federal e os Municípios e com os partidos políticos, para a Casa Civil da Presidência da República;" (art 32, I). Foram também transferidos 
"da Secretaria-Geral da Presidência da República, a Secretaria de Assuntos Federativos e a Secretaria de Assuntos Parlamentares, para a Casa Civil da Presidência da República, passando a denominar-se, respectivamente, Subchefia de Assuntos Federativos e Subchefia de Assuntos Parlamentares;". (art. 33, II)

Em resumo, após as diversas configurações apresentadas, com a lei 11204/05 os três principais órgãos de assessoramento da Presidência da República que compõem a estrutura de gestão da participação social no governo Lula são a Casa Civil, a Secretaria de Assuntos Institucionais e a Secretaria-Geral. Compete à Casa Civil coordenar e integrar as ações do Governo; avaliar e monitorar a ação governamental e dos órgãos e entidades da Administração Pública Federal; além de apoiar o Conselho Superior de Cinema e o Conselho Deliberativo do Sistema de Proteção da Amazônia. À Secretaria de Relações Institucionais compete a coordenação política do Governo; a condução do relacionamento do Governo com o Congresso Nacional e os Partidos Políticos; a interlocução com os Estados, o Distrito Federal e os Municípios; bem como a coordenação do Conselho de Desenvolvimento Econômico e Social. Já a Secretaria-Geral cabe o relacionamento e a articulação com as entidades da sociedade civil; além da criação e da implementação de instrumentos de consulta e participação popular.

Esta distribuição de funções entre órgãos de assessoramento da Presidência conformou a estrutura de gestão no que diz respeito a articulação com atores políticos e a assuntos relevantes à participação. Foi no âmbito da Secretaria-Geral, sob a coordenação de Luiz Dulci, que o governo empreendeu ações para a ampliação da participação social de forma integrada com outros órgãos do governo federal.

No âmbito interno, foi criado em 2003 o Fórum Governamental de Participação Social, "instrumento legal instituído com o objetivo de articular os diversos canais de participação social” (SECRETARIA-GERAL, 2005:5), coordenado pela Secretaria-Geral e formado pelos assessores responsáveis em todos os Ministérios pelo diálogo e articulação com a sociedade civil, com a finalidade de:

"I - propor diretrizes para a formulação de políticas voltadas para a ampliação da participação social no âmbito do Governo Federal; 
II - apreciar propostas, inclusive de reformas estruturais, que visem à ampliação da participação social, da prática da democracia, da ética e transparência das ações e da fiscalização dos atos do Poder Público;

III - articular e dinamizar as relações do Governo Federal com a sociedade civil, fortalecendo a participação da sociedade no processo de aperfeiçoamento dos serviços oferecidos pelo Estado;

IV - estimular as organizações públicas a investir em inovações e na formulação de políticas que ampliem a participação social, observadas as diretrizes estabelecidas; e

V - propor a adoção de instrumentos de participação e controle social nas fases estratégicas de formulação, implementação, acompanhamento, monitoramento e avaliação de políticas públicas de responsabilidade de cada Ministério e Secretaria Especial." (Decreto sem número de 15/12/2003)

Na Secretaria-Geral foi criada a Secretaria Nacional de Articulação Social. A ela coube: "I - coordenar e articular as relações políticas do Governo com os diferentes segmentos da sociedade civil; e II - propor a criação, promover e acompanhar a implementação de instrumentos de consulta e participação popular de interesse do Poder Executivo." (decreto n 5364)

"Uma das primeiras questões colocadas pelo governo Lula foi o desenho institucional ou a arquitetura da participação. Se pegarmos o desenho inicial, podemos concluir duas coisas: a participação era vista como estratégia de governabilidade e os sujeitos políticos da participação eram reconhecidos com pesos diferentes." (MORONI, 2005:13) Os pesos diferenciados são evidenciados na separação da relação com a sociedade civil organizada e com atores políticos tradicionais. A Secretaria-Geral especializou-se na relação com a sociedade civil e a Casa Civil, em um primeiro momento, e depois a Secretaria de Relações Institucionais cuidaram da política com partidos políticos e até do Conselho de Desenvolvimento Econômico e Social.

$\mathrm{Na}$ estrutura de gestão, o reconhecimento de novos atores políticos como elemento caracterizador do modo petista de governar fica comprometido por esta separação entre os órgãos que articulam diferentes atores políticos. $\mathrm{O}$ fato de haver menção expressa à articulação com a sociedade civil, por si só, não garante esse reconhecimento. Isso é explícito quando vemos o arranjo institucional que deixa o Conselho de Desenvolvimento Econômico e Social sob 
coordenação da Secretaria de Relações Institucionais, a responsável pela articulação política e não pela articulação com a sociedade.

Além disso, a abertura do Estado, que possibilita o controle social e a efetivação da participação social, fica prejudicada no arranjo institucional que separa a articulação com a sociedade da integração das ações governamentais. Assim, num governo marcado pela política de alianças, que em certos casos coloca setores governamentais em embate por serem geridos a partir de posições ideológicas díspares, há o risco de as articulações com a sociedade ficarem à parte das ações de integração inter-governamental.

Mesmo com essas deficiências na estrutura de gestão, o governo empreendeu diversas iniciativas para criação de novas esferas públicas democráticas. Assim, passamos a delinear as principais ações de governo relacionadas à participação social.

\subsection{Ações de governo}

No decorrer do governo foram realizadas ações no sentido de ampliar a participação da sociedade na formulação, implementação, acompanhamento, monitoramento e avaliação de políticas públicas. Segundo o próprio governo, "o exercício da democracia participativa se efetivou com a criação e realização dos Conselhos de Direitos, Ouvidorias, Mesas e Conferências Nacionais por ministérios e secretarias especiais do governo federal" (SECRETARIA-GERAL, 2005:10). Foram criados novos canais de participação e consolidados os já existentes. Antes de analisarmos o caso das Conferências Nacionais, descreveremos ações importantes na ampliação da participação social no governo Lula.

No delineamento das ações de governo concernentes à participação social, inicialmente deve-se ressaltar o processo de discussão do Plano Plurianual 2004-2007 - PPA. Realizado no primeiro ano de governo, reuniu em audiências públicas, em todas as unidades da federação, mais de duas mil entidades sociais para o debate de investimentos do Governo Federal. O processo foi coordenado pela Secretaria-Geral em parceria com a Associação Brasileira de Organizações Não-Governamentais - Abong. 
Esse processo de debate acerca do PPA foi marcado pelo tempo exíguo para o aprofundamento das questões e pelo não-detalhamento dos programas. Segundo Moroni, a sociedade civil aceitou participar sabendo dos limites, pois havia compromisso com a continuidade do debate. No entanto, os compromissos não foram cumpridos pelo Governo Federal (MORONI, 2005:16-17).

\begin{abstract}
"Os acordos eram: criação de espaço institucional para a continuidade do processo (fórum permanente de acompanhamento do processo orçamentário), criação de indicadores desagregados por região, gênero, etnia (grupo de trabalho no Ministério do Planejamento) e acesso universal aos sistemas de informações do orçamento (como o Sistema Integrado de Administração Financeira/Siafi, o Sistema de Informações Gerenciais e de Planejamento/Sigplan etc.).” (MORONI, 2005:16)
\end{abstract}

Fora do âmbito do PPA, audiências públicas e mesas de negociação foram realizadas em temas como transposição do Rio São Francisco, plano de desenvolvimento sustentável da BR-163 e aumento do salário mínimo. Foi um "processo de interlocução com a sociedade" em que o governo colheu "subsídios para implementar e aperfeiçoar seus programas e políticas públicas, ouvindo e incorporando sugestões da população diretamente beneficiada." (SECRETARIA-GERAL, 2005:6).

Mesmo com a ampliação de canais para escuta das demandas, esses espaços não foram suficientes e definidores de políticas em casos polêmicos como o da transposição do Rio São Francico. Isso ficou explícito quando o governo ignorou deliberações do Comitê de Bacia Hidrográfica do São Francisco e insistiu no projeto. A proposta federal acabou por ser adiada por muitas manifestações da sociedade que exigiam, entre outras coisas, transparência no processo e ampliação da participação popular na decisão, pois o governo se recusou a "aceitar os resultados dos poucos espaços de debates existentes, quando esses se mostram contrários ao projeto" (ASSEMBLÉIA POPULAR, 2005).

No decorrer dos três primeiros anos de governo, foram criadas 84 novas ouvidorias na estrutura da administração federal. Segundo o governo, representaram "esforços do governo brasileiro de valorizar os canais de participação social para o exercício da cidadania" 
(SECRETARIA-GERAL, 2006:16). Nesse âmbito, a estrutura da Controladoria-Geral da União foi reforçada e fóruns de debates entre gestores de ouvidorias foram realizados.

Cabe refletir sobre o caráter desses canais abertos com a população para receber críticas, sugestões, elogios e também tirar dúvidas sobre o desempenho de órgãos públicos. Originária dos países escandinavos, ainda no século XVI, a figura do ombudsman estava ligada ao Parlamento e possuía poderes de controle dos atos do poder público. No Brasil, foi o Ministério Público que assumiu a função independente de ação diante dos desmandos da administração pública (SILVA, 2002). As ouvidorias, em que pese a importância para o esclarecimento e o encaminhamento de críticas, estão mais para a lógica em que o cidadão é um cliente de serviços e bens públicos encaminhando suas questões individualmente que para a visão de um cidadão sujeito de direitos e membro de uma comunidade organizada que dialoga com o governo a respeito dos assuntos públicos. Assim, ouvidorias não estariam nos esforços de criação de novas esferas públicas democráticas, embora o governo as inclua como instrumentos de participação social.

A visão de conselhos como espaços estratégicos de participação social é explicitada com a revitalização do Conselho Nacional de Segurança Alimentar e Nutricional logo no início do governo, com a criação do Conselho de Desenvolvimento Econômico e Social e de diversos outros conselhos como canais de interlocução entre governo e sociedade. Moroni faz uma leitura crítica desses mecanismos:

\footnotetext{
"Os conselhos ainda são mecanismos, não os únicos, de participação. Porém, não como se apresentam hoje, sem espaço para o debate político, a deliberação e o controle social, ou seja, espaços formais ou de faz de conta de participação. Isso também reflete a maneira como são escolhidas as pessoas para a representação da sociedade civil, que não se vêem como representação da sociedade civil, mas muito mais como representação de interesses da sua organização. Tal processo foi agravado - e muito - nos novos espaços criados no governo Lula, pois não há eleição, e sim indicação do próprio governo de quem representará a sociedade (excetuando o Conselho das Cidades).” (MORONI, 2005:17)
}

A criação do Conselho de Desenvolvimento Econômico e Social foi caso emblemático nesse sentido e, como espaço de debate em torno de temas relevantes para o desenvolvimento do país, fez valer a tese da bipolaridade da relação capital-trabalho na visão de 
participação social no governo Lula. "Acostumado a lidar com o movimento sindical e ainda com uma concepção de que a sociedade se organiza apenas em torno dos interesses da relação capitaltrabalho, o governo Lula não conseguia - e não consegue - dialogar com esse conjunto de organizações e movimentos, pois acha que 'isso tudo é muito difuso', pois não possui uma 'central' e muito menos um 'presidente'." (MORONI, 2005:15)

Além destas críticas, os conflitos entre representantes do Estado e de organizações da sociedade civil foram evidenciados em concepções de participação como modelo de gestão ou como processo de democratização:

\begin{abstract}
"Uma concepção (implícita em gestores governamentais) entende a participação como um modelo de gestão da política pública, e a outra (implícita em representantes da sociedade civil) compreende-a como processo de democratização da política pública. Isso não significa que gestores não se interessem pela democratização dos processos, nem que representantes de organizações da sociedade civil considerem irrelevante a gestão da política. Significa, sim, que as nuanças possíveis - quaisquer que sejam - não podem obscurecer o fato de que as posições ocupadas nos espaços públicos pelos dois tipos de atores tendem a localizá-los prioritariamente no lado da gestão ou no lado da democratização das políticas." (DELGADO \& LIMONCIC, 2005:11)
\end{abstract}

Ao lado dos conselhos, as conferências nacionais foram maneiras para "viabilizar o diálogo social permanente e um vasto processo de democracia participativa" (SECRETARIA-GERAL，2006:3). Foram realizadas 32 conferências nacionais com a participação de mais de dois milhões de brasileiras e brasileiros em etapas municipais, estaduais e nacionais. (ibit) Por serem os espaços mais amplos de participação, tendo em vista a quantidade de participantes e a possibilidade de interlocução direta entre Estado e Sociedade, passamos a analisar esta experiência como referencial das ações de governo para a criação de novas esferas públicas democráticas. 


\section{A EXPERIÊNCIA DAS CONFERÊNCIAS NACIONAIS}

Para a análise do modo petista de governar em nível federal, no que diz respeito à participação social, é necessário observar o ciclo de Conferências como fator de institucionalização da participação. "A nosso ver, a aposta na institucionalização e sustentabilidade de um sistema de participação de tal envergadura representa um esforço inédito na história do país.” (MARICATO \& SANTOS JÚNIOR, 2006:28)

Foi em 1937 que a legislação brasileira previu o mecanismo de Conferências Nacionais iniciadas com as áreas de saúde e educação. A I Conferência Nacional de Saúde foi realizada em 1941 e reuniu "representantes dos órgãos públicos de saúde na esfera federal e estadual, para discussão e deliberação das questões administrativas relativas à saúde pública" (HOCHMAN, 2005:133). Posteriormente, a sociedade civil inicia mobilização e passa a participar desse espaço de discussão da Política Nacional de Saúde.

A tradição das Conferências de Sáude (13 ${ }^{\mathrm{a}}$ edição prevista para 2007) e do Sistema Único de Saúde parece ter sido inspiração para outras áreas durante o ciclo de Conferências do governo Lula. A experiência e a força simbólica da Conferência de Saúde foram base para o desenho dos processos de participação nas Conferências, com a devida adaptação às especificidades de cada setor (Entrevistada 4).

Foram realizadas conferências em diversas áreas como: Aqüicultura e Pesca; Arranjos Produtivos Locais; Assistência Social; Cidades; Ciência, Tecnologia e Inovação em Saúde; Ciência, Tecnologia e Inovação; Cultura; Direitos da Criança e do Adolescente; Direitos da Pessoa com Deficiência; Direitos da Pessoa Idosa; Direitos Humanos; Economia Solidária; Educação Profissional e Tecnológica; Esporte; Gestão do Trabalho e da Educação na Saúde; Infanto-Juvenil do Meio Ambiente; Medicamentos e Assistência Farmacêutica; Meio Ambiente; Políticas para as Mulheres; Povos Indígenas; Promoção da Igualdade Racial; Saúde Bucal; Saúde 
do Trabalhador; Saúde Indígena; Saúde; e Segurança Alimentar e Nutricional. (SECRETARIAGERAL, 2006:9)

Os processos de mobilização variaram em cada setor. Em seu conjunto, as conferências nas diversas instâncias, como já referido, reuniram mais de dois milhões de pessoas e a postura de incentivo ao espaço de diálogo foi marcante. "Nas conferências realizadas em governos anteriores, quem organizava e comandava tudo era a sociedade civil. O governo aparecia como um espectador e ia embora. Agora, esses espaços têm registrado uma qualidade e uma participação governamental bem diferente do que estávamos acostumados. O positivo disso é que as conferências viraram espaços de disputas políticas.” (MORONI, 2005:18)

$\mathrm{Na}$ análise de Maricato e Santos, essa postura diferenciada, ao abrir canais de diálogo sem a intenção de subordinar interesses, possibilitou a emergência de "conflitos que sempre foram sufocados pela tradição política brasileira" (MARICATO \& SANTOS JÚNIOR, 2006:30). No entanto, a realização de empreendimento de tal amplitude teve contradições como a baixa integração entre ministérios afins às temáticas das Conferências, ficando as deliberações restritas à capacidade de gestão e de articulação dos ministérios que as convocavam (Entrevistado 1; Entrevistado 2 e Entrevistado 3). As Conferências se constituiram em "institucionalidades paralelas: conservadas à margem e com difícil interlocução com o resto do aparato estatal" (CAMURÇA, 2006:36).

Na experiência das Conferências Nacionais, ocorreram "avanços significativos, mas também ficaram claros os limites encontrados, sobretudo a restrição orçamentária" (MENEZES, 2006:33). Silvia Maria Sampaio Camurça, ao avaliar a Conferência Nacional de Políticas para Mulheres, afirma que o momento de realização dessa e de outras Conferências não foi favorável, pois, por terem sido realizadas após a aprovação do PPA, "não reorientaram substantivamente a ação governamental nem a política de ajuste fiscal - o que termina por reduzir significativamente os impactos de curto prazo, por força dos parcos investimentos adicionais que geraram" (CAMURÇA, 2006:36).

Mesmo enfrentando dificuldades e limites, tanto por parte do governo como da sociedade civil, as Conferências, como instrumentos de gestão democrática, marcaram o governo 
Lula no que diz respeito à participação social. Com a finalidade de concentrarmos ainda mais o foco do olhar sobre o modo petista de governar, passamos à breve descrição e análise de dois casos representativos: as Conferências Nacionais de Meio Ambiente e a Conferência Nacional de Cultura.

\subsection{Conferências Nacionais de Meio Ambiente}

\subsubsection{Descrição}

$\mathrm{Na}$ formulação do Plano de Governo para a campanha eleitoral foi elaborado um caderno temático sobre Meio Ambiente e Qualidade de Vida. Entre as diretrizes de gestão existiam menções à participação e ao controle social, além de proposta específica referente à realização da Conferência Nacional: "Realizar um amplo debate sobre os grandes problemas do país na área ambiental e a implementação da Agenda 21, a partir de conferências estaduais e municipais, a ser realizada em conjunto com uma Bienal do Desenvolvimento Sustentável mostra nacional e internacional de projetos, saber científico e popular, tecnologia apropriada e negócios sustentáveis" (PT, 2002d:13).

Ao assumir o Ministério do Meio Ambiente em janeiro de 2003, Marina Silva, senadora pelo PT do Acre e reconhecida ativista ambiental, delineou quatro diretrizes para a política ambiental integrada de sua gestão: "desenvolvimento sustentável, transversalidade, fortalecimento do Sistema Nacional de Meio Ambiente (SISNAMA) e participação e controle social." (Entrevistado 1). O eixo "participação e controle social" contou com ações como fortalecimento de Conselhos e outros órgãos colegiados, consultas populares, disponibilização de informações e, destaque para o compromisso de campanha, Conferências Nacionais.

Com a força simbólica da convocação Vamos Cuidar do Brasil, foram mobilizadas em 2003, na I Conferência Nacional do Meio Ambiente, 68 mil participantes em préconferências nacionais, tendo como tema e objetivo o fortalecimento do SISNAMA. Em dez estados, os governos estaduais convocaram conferências estaduais que deliberaram sobre políticas ambientais locais. Para a mobilização foram constituídas comissões organizadoras estaduais coordenadas pelo Instituto Brasileiro do Meio Ambiente e dos Recursos Nacionais 
Renováveis - IBAMA e compostas por representantes da sociedade, do governo e de entidades empresariais. A coordenação nacional acompanhou o processo de mobilização nos estados enviando periodicamente técnicos-articuladores. Para a realização do processo foram repassados recursos do governo federal às comissões organizadoras estaduais (MMA, 2004).

A metodologia dos eventos estaduais consistia na aprovação do regimento interno e discussão de texto-base, elaborado pelo Ministério do Meio Ambiente. Em grupos temáticos, os participantes formulavam propostas que, aprovadas por maioria simples em plenária final, seguiam como emendas ao documento inicial. As plenárias das conferências também votavam moções e procediam a eleições dos delegados, na proporção de 1 delegado para cada 25 participantes, considerando o mínimo de $30 \%$ de gênero, e mínimo de 8 e máximo de 50 delegados por estado (MMA, 2004).

No evento nacional, realizado em dezembro de 2003 em Brasília, participaram 912 delegados, sendo 37\% mulheres e 63\% homens; $33 \%$ representantes de governo $(35 \%$ de municípios, $38 \%$ de estados e $27 \%$ do governo federal); $41 \%$ da sociedade civil; $19 \%$ de universidades; e 7\% do setor empresarial. Além desses, foram delegados natos à Conferência Nacional todos os membros efetivos do Conselho Nacional do Meio Ambiente e do Conselho Nacional de Recursos Hídricos (MMA, 2004).

Foram recebidas 4.151 emendas ao texto-base (MMA, 2004). Essas propostas, sistematizadas, compuseram um novo texto-base que foi apreciado pelos delegados na Conferência Nacional com a mesma metodologia. A plenária-final aprovou 659 propostas, sendo que 323 eram de competência do Ministério do Meio Ambiente e 336 referiram-se "à área de atuação de outros órgãos e instituições do governo, tanto em nível federal quanto estadual e municipal" (MMA, 2005:5).

Por orientação da Ministra, tendo em vista a inexistência de legislação nesse sentido, as propostas aprovadas que competiam ao Ministério do Meio Ambiente foram percebidas como deliberações (Entrevistado 1). Foi constituído, pois, grupo de trabalho para o acompanhamento das ações e, até dezembro de 2005, já haviam sido implementadas ou estavam em implementação $62 \%$ das ações referente à área de atuação do Ministério do Meio Ambiente 
(MMA, 2005:5). Na perspectiva da transversalidade das políticas, foram intentadas articulações com outros órgãos federais para execução das ações, além da constituição das comissões tripartites cujo objetivo é levar as ações de competência dos estados e municípios aos gestores responsáveis (Entrevistado 1). Para as deliberações que extrapolaram o âmbito do ministério, $50,9 \%$ do total, não encontramos estatísticas de implementação.

Como parte das deliberações da I Conferência, o Ministério do Meio Ambiente convocou a II Conferência Nacional do Meio Ambiente que foi realizada em dezembro de 2005, em Brasília. A mobilização na II Conferência atingiu 86 mil participantes nas pré-conferências, apontando basicamente a mesma metodologia, havendo melhorias qualitativas, segundo o coordenador do processo, com mais objetividade no texto-base, definição de cotas de participação por segmentos sociais, fortalecimento das conferências regionais e constituição de comissão interministerial para acompanhamento das deliberações (Entrevistado 1).

O evento nacional reuniu 1337 delegados, sendo $62 \%$ homens e $38 \%$ mulheres, $50 \%$ da sociedade civil, $21 \%$ do setor empresarial e $29 \%$ do governo ${ }^{1}$ (MMA, 2006a:11). Foram aprovadas 831 propostas, sendo 425 de competência do Ministério do Meio Ambiente, 356 de competência compartilhada e 50 de competência externa (MMA, 2006b). Foi mantida a proporção da I Conferência de aproximadamente metade de deliberações de competência interna e metade compartilhada ou externa.

Novamente foi constituído um Grupo de Trabalho para acompanhar as ações, sendo que este terá a função de disponibilizar o sistema de acompanhamento de deliberações na Internet (MMA, 2006a:10). Além disso, já prepara a terceira edição do processo previsto para 2007, bem como "trabalha na elaboração de mecanismo legal para institucionalizar a Conferência tornando-a política de Estado" (Entrevistado 1). A institucionalização foi aprovada prevendo a Conferência como "instrumento de instância deliberativa da política de meio ambiente integrante do SISNAMA", a ser convocada a cada dois anos (MMA, 2006b:90).

Com esta breve descrição dos processos das Conferências Nacionais de Meio Ambiente, podemos analisar esse mecanismo de participação social com base nos elementos

\footnotetext{
${ }^{1}$ Dados aproximados, tendo em vista os resultados da pesquisa realizada com delegados. (MMA, 2006a)
} 
caracterizadores do modo petista de governar apontados na seção 3 deste trabalho, a saber: criação de novas esferas públicas democráticas, abertura do Estado e redefinição dos atores políticos.

\subsubsection{Análise}

O primeiro elemento caracterizador do modo petista de governar é a criação de novas esferas públicas democráticas. Diz respeito ao lugar, ou instância, em que a política se faz e cabe analisarmos a partir das características necessárias a essas esferas: auto-regulação, abertura para explicitação de interesses e conflitos, e interação entre Estado e Sociedade para discussão e negociação de políticas públicas.

Na Conferência Nacional de Meio Ambiente, em suas duas edições, houve oportunidade de auto-regulação com a discussão e aprovação do regimento interno no início das pré-conferências e da etapa nacional. Além disso, a segunda edição foi explícita ao deliberar pela institucionalização do processo, vinculando esta instância de participação ao SISNAMA com poder deliberativo sobre as políticas ambientais (MMA, 2006b:90). Segundo o coordenador da II Conferência, na medida em que a Conferência se afirma e se institucionaliza a resposta de estados e municípios pode ser diferenciada (Entrevistado 1). No entanto, cabe ressaltar que a continuidade do processo não é garantida via legislação (DANIEL, 1999:234).

Nas duas edições da Conferência, houve abertura para explicitação de interesses e conflitos. Isso pode ser percebido na lógica interna de discussão por grupos temáticos com deliberações por votação. Aconteceu uma tentativa de construção de metodologia diferenciada na primeira edição, mas disputas internas no processo de gestão impediram os avanços (Conversas com integrantes da equipe). As disputas de posições entre grupos com interesses contrários foram vivenciadas e resolvidas, na I Conferência, no voto. Na segunda edição, a plenária teve oportunidade de negociar temas em separado permitindo votações ou aclamações consensuadas. Essa predisposição em organizar o processo de debate na plenária, de forma diferenciada, não impediu o prolongamento das atividades da plenária final pela madrugada, o que impossibilitou o término das votações de moções e a participação de inúmeros participantes que, em alguns casos, chegaram a dormir no auditório para que houvesse quórum (Conversas com participantes). 
A efetiva apropriação do espaço pela sociedade, que permitiria interação efetiva entre Estado e Sociedade para discussão e negociação de políticas públicas, não aconteceu na I Conferência. Isso foi evidenciado, na avaliação da Coordenadora da Conferência, pela fragilidade de certas deliberações que não refletiram os acúmulos de debates históricos do movimento ambientalista (Entrevistada 4). Por outro lado, em pesquisa com os participantes da II Conferência foi formulada questão aberta a respeito do maior acerto da política ambiental do governo e $21 \%$ dos entrevistados mencionaram a participação da sociedade em instâncias de decisão e de formulação de políticas públicas (MMA, 2006a:33).

A abertura do Estado também compõe o modo petista de governar, resignificando a política na perspectiva de como se faz a gestão. Para a análise, podemos apontar os seguintes aspectos: ruptura com racionalidade burocrática e verticalizada, transparência, e incorporação da concepção de gestão democrática às práticas administrativas.

No que diz respeito à racionalidade burocrática e verticalizada, a Conferência não rompeu com padrões tradicionais quando o texto-base foi proposto pelo Ministério do Meio Ambiente, sem espaço para formulação conjunta com a sociedade. Embora, nas duas edições existissem comissões organizadoras nacionais integradas também pela sociedade civil, o papel legitimador das ações do Ministério e o valor simbólico eram explícitos (Conversas com integrantes da equipe). A baixa integração das três instâncias de governo ao processo fez que a Conferência se distanciasse das realidades locais, pois, nos estados e municípios que as comissões organizadoras locais não formularam documentos para discussão, o debate girou em torno das teses do documento enviado pelo governo federal. Ademais, na I Conferência parecia haver, por parte de alguns dirigentes, medo de como seriam as deliberações oriundas do processo. Isso gerou disputas internas entre visões de participação plena e de domesticação da participação (Entrevistada 4).

Com relação à transparência, existiram esforços, a partir da realização da I Conferência, no sentido de disponibilizar à sociedade informações a respeito do processo de implementação de deliberações de competência do Ministério do Meio Ambiente (Entrevistado 1). O mesmo não foi possível observar nos outros órgãos federais e por parte das outras instâncias federativas envolvidas. Além disso, a transparência não está limitada à implementação de 
deliberações, mas, em especial, à disponibilização de informações no decorrer das discussões para que possa ocorrer efetivo controle social e formulação de propostas condizentes à realidade. Na pesquisa com delegados da II Conferência, figura a centralização do poder entre os maiores erros da política ambiental do governo (MMA, 2006a:35). Esse aspecto pode apontar para a necessidade de avançar na transparência, mas também na descentralização da gestão.

Cabe menção, no que tange à gestão descentralizada, à criação pelo Ministério do Meio Ambiente de comissões tripartites - espaços de diálogo entre os órgãos e entidades ambientais da administração pública federal, estadual e municipal, cujo objetivo é a promoção da gestão ambiental compartilhada e descentralizada. Dessa forma, concretiza-se a visão da abertura do Estado, realizada plenamente com a incorporação da concepção de gestão democrática às práticas administrativas. Mas esse fator não é nítido para análise, tendo em vista que envolve ações de esclarecimento, persuasão e treinamento do funcionalismo, o que não conseguimos observar no espaço da Conferência.

Por último, consideraremos o elemento redefinição dos atores políticos que se configura na perspectiva de alterar a percepção sobre quem faz política. Na análise devem ser observados: o reconhecimento da pluralidade de atores políticos, o fortalecimento autônomo da sociedade organizada, a existência de espaço para população não-organizada e a legitimação do governo como ator no processo.

O reconhecimento da pluralidade de atores políticos se faz necessário não apenas por aqueles que convocam esferas públicas democráticas, mas por todos que dessas participam. Por parte do Ministério, houve esse reconhecimento com o incentivo a conferências setoriais, garantia mínima de $30 \%$ de gênero e cotas para os setores sociais, governamentais e empresariais. Inclusive, o reconhecimento da pluralidade de atores políticos é notório com as proporções de participação, acima elencadas, nas edições da Conferência Nacional. Cabe mencionar a necessidade de reconhecimento mútuo entre os setores participantes, o que parece não ter havido, em particular, por parte do setor empresarial na I Conferência, quando "teve dificuldade de perceber a inserção de outros atores sociais na discussão" (Entrevistada 4). Isso acabou por gerar conflitos com a sociedade civil pela diferença nas práticas de negociação e diálogo. 
Tornar o processo de participação uma ocasião para controle social das ações governamentais, não uma instância de legitimação, parece ser o desafio quando se fala de fortalecimento autônomo da sociedade organizada. O dilema, já mencionado neste trabalho, entre ser governo e movimento acaba por enfraquecer a capacidade de reivindicação da sociedade civil. Assim, a incorporação de ativistas ambientais ao governo embora dê espaço para posturas condizentes com gestão democrática (Entrevistado 1), acaba por esvaziar os movimentos populares quando integrantes qualificados passam a ser governo.

Nas duas edições da Conferência existiu espaço para participação da população não-organizada. Isto aconteceu, em especial, nas pré-conferências, pois a capacidade de articulação, condição para obtenção dos votos necessários à eleição como delegado para a etapa nacional, é recurso disponível, em maior grau, a integrantes de organizações e movimentos sociais acostumados com processos de disputa política. Pessoas provenientes da população nãoorganizada, em sua maioria inexperientes em processos de disputa política, tiveram oportunidade de participação o que contribui para o aprendizado de formas organizativas e conseqüente renovação de lideranças. O objetivo pedagógico permeia também as ações do Ministério na Conferência, no sentido do esclarecimento sobre o SISNAMA (MMA, 2004). No entanto, não existiram ações de incentivo específicas à participação da população não-organizada.

Cabe mencionar o reconhecimento do governo como ator no processo dada a garantia de participação de gestores locais, municipais e federais. No entanto, como a disputa interna entre participação tutelada e plenitude do processo reverberou na forma de organização das pré-conferências na primeira edição, houve desconfiança por parte de alguns setores sociais no que diz respeito à atuação governamental (Entrevistada 4).

Ao analisarmos as Conferências de Meio Ambiente é prudente também observarmos uma outra experiência que pode colaborar na composição do olhar sobre o modo petista de governar. Para tal, foi escolhida a Conferência Nacional de Cultura, por apresentar contra-ponto metodológico ao processo deliberativo desenvolvido na área ambiental. 


\subsection{Conferência Nacional de Cultura}

\subsubsection{Descrição}

O campo cultural não contou com caderno temático no programa de governo e não existiu menção expressa a canais de participação popular. Apenas há referência genérica, na seção que trata da educação e da cultura, ao diálogo permanente com a sociedade civil. Chega a afirmar: "Uma das tragédias do Brasil tem sido a incapacidade dos dirigentes de estabelecer pontes, acordos, entendimentos com os quais todos possam ganhar." (PT, 2002b:15) Além dessas generalidades, não houve compromisso de campanha com relação à Conferência.

O Ministro da Cultura, Gilberto Gil, renomado cantor, na época filiado ao Partido Verde, ao assumir o cargo em janeiro de 2003 iniciou trabalho pela reestruturação administrativa do órgão. Criou uma Secretaria de Articulação Institucional que, entre outras atribuições, deve promover a integração de programas culturais federais e das outras instâncias, além de "coordenar a implementação dos fóruns de política cultural, responsáveis pela articulação entre o Ministério e a comunidade cultural" (Artigo 12, inciso III, do anexo I do Decreto 5711 de 24 de fevereiro de 2003). Em março de 2005, foi criada a Gerência de Participação Social, no âmbito desta secretaria, que coordenou o processo da I Conferência Nacional de Cultura (Entrevistado 2).

Por decisão dos gestores, a partir da realidade encontrada no setor cultural do país, a prioridade foi o trabalho na articulação do Sistema Nacional de Cultura. Neste processo, se destaca a articulação entre os entes da federação e a gestão democrática da política cultural. Mesmo sem a consolidação do sistema, algumas iniciativas de participação social foram empreendidas, no âmbito do Ministério da Cultura, como os Seminários Cultura para Todos, o Seminário Nacional de Culturas Populares e a redefinição da composição e das atribuições do Conselho Nacional de Política Cultural. A I Conferência Nacional de Cultura aconteceu no terceiro ano de governo, tendo a etapa nacional ocorrido, em Dezembro de 2005, em Brasília (Entrevistado 2). 
A Conferência foi convocada com caráter consultivo para a formulação de subsídios e priorização de diretrizes a serem apreciadas na formulação do Plano Nacional de Cultura. O Ministério da Cultura estimulou municípios a realizarem conferências municipais ou unirem-se em conferências inter-municipais e encaminharem propostas e delegados à etapa nacional. O Ministério também organizou um seminário em cada região brasileira com a mesma finalidade, sendo garantida a representação da sociedade civil e de gestores públicos. Em ambas as formas de etapas preparatórias o Ministério enviou texto orientador do debate, mas sem o caráter de texto-base a ser emendado. Foram mobilizadas cerca de 50 mil pessoas, em 1060 municípios, produzindo mais de três mil propostas (Conversas com integrantes da equipe).

A Conferência Nacional reuniu aproximadamente 1200 pessoas entre delegados do poder público e da sociedade civil, observadores e convidados. Foram 847 delegados, sendo $26 \%$ do poder público e $74 \%$ da sociedade civil (MINC, 2005a). A Conferência seguiu a lógica da priorização em sua metodologia, partindo de grupos de discussão por sub-eixos temáticos em que, na primeira rodada, a partir da leitura das propostas enviadas pelos estados, os participantes indicaram seis diretrizes, até à plenária que indicou 30 propostas de diretrizes prioritárias. Após a primeira rodada de discussão foi realizado o momento interativo em que, no local do almoço, foram afixados painéis para que os participantes individualmente fizessem contribuições por escrito para a discussão da segunda rodada de grupos nos quais não participavam. Cada um escolheu até três propostas para comentar por escrito, e até cinco para indicar como prioritárias. Participantes explicaram aos componentes de outros grupos as motivações das propostas formuladas, ouviram críticas e defenderam idéias. Na segunda rodada de discussão, a partir da análise das indicações e comentários do momento interativo, os participantes ampliaram e aprofundaram a discussão sobre as propostas com o objetivo de estabelecer três propostas de diretrizes prioritárias. Na plenária, as propostas dos grupos foram apresentadas e discutidas por eixo temático. Após a discussão de cada eixo, os participantes indicaram, em cartões para leitura ótica, o grau de prioridade que consideraram para cada proposta - alta, média ou baixa prioridade (MINC, 2005b). Por fim, foram apresentadas 63 propostas de diretrizes, sendo 30 prioritárias, em escala de prioridade (MINC, 2005a).

Os resultados da Conferência foram encaminhados aos gestores do Ministério da Cultura responsáveis pela formulação do Plano Nacional de Cultura que, em diálogo com o 
Conselho Nacional de Políticas Culturais, finalizarão a proposta para envio ao Congresso Nacional (MINC, 2005b). Desta forma, a Conferência foi consultiva no contexto de formulação da Política Nacional, haja visto, que as propostas priorizadas serão subsídios para a elaboração do documento a ser encaminhado ao Congresso (Entrevistado 2).

Com essa descrição dos aspectos centrais do processo de mobilização, da metodologia do evento e do caráter da I Conferência Nacional de Cultura, podemos passar a análise a partir dos elementos caracterizadores do modo petista de governar.

\subsubsection{Análise}

No que diz respeito à criação de novas esferas públicas democráticas, observaremos as características necessárias às instâncias de participação: auto-regulação, abertura para explicitação de interesses e conflitos, e interação entre Estado e Sociedade para discussão e negociação de políticas públicas.

No aspecto auto-regulação, não houve espaço para discussão e aprovação do regulamento da Conferência Nacional de Cultura. Na etapa nacional, o texto foi apresentado como dado para não haver questionamento à lógica da priorização e à metodologia do evento. Como estratégia de convencimento foi realizada, no primeiro dia do evento, uma atividade de esclarecimento sobre a metodologia (MINC, 2005b). Nas etapas prévias, houve sinalização de modelos de regulamento, mas coube às instâncias locais a própria regulação (Conversas com integrantes da equipe). A fragilidade nesse ponto da construção do canal de participação aponta para possíveis entraves na continuidade do processo.

Segundo o coordenador da Conferência, a área cultural não tem conflitos demarcados entre setores, como a ambiental, o que ocorre pela fluidez do campo e pela impermanência das organizações da sociedade civil (Entrevistado 2). Assim, a explicitação de interesses e conflitos foi estimulada, mas pela especificidade do movimento cultural, as convergências foram enfatizadas com a lógica da priorização de propostas. Na etapa nacional e nos seminários regionais os participantes dialogaram, formulando propostas, e indicaram as prioritárias. Esta abordagem é uma opção que "fortalece o processo participativo em sua 
capacidade propositiva" (ROMBAUER \& SOUZA, 2006), tendo em vista que a priorização acaba acontecendo pelos gestores, haja visto a limitação de recursos para a implementação das ações. Portanto, priorizar com a participação da sociedade traz mais eficiência à decisão de qual política pública realizar. Isso fica explícito com o caso da Conferência, em que os gestores não imaginavam que a proposta prioritária seria ligada à questão da comunicação e não do orçamento ou do sistema nacional de cultura (Entrevistado 2). Outra inovação metodológica foi a interatividade entre os grupos de discussão. Com a finalidade de ampliar a possibilidade dos participantes de intervirem para além de apenas um grupo e para que pudessem participar de modo mais amplo, reduzindo sobreposições de propostas, foi realizado o momento interativo. "A interação entre etapas do trabalho em grupos também favorece significativamente a etapa posterior, em plenária. Os participantes percebem suas idéias mais contempladas nas propostas, e alguns pontos de conflito podem ser considerados e dirimidos nos grupos de discussão, o que possibilita debate mais focado em plenária." (ROMBAUER \& SOUZA, 2006) As inovações metodológicas empreendidas permitiram que interesses e conflitos pudessem ser expressos, fortalecendo o processo consultivo para formulação do Plano Nacional de Cultura.

Existiu interação entre Estado e Sociedade, mas o caráter consultivo do processo não gerou a plenitude da possibilidade da relação com vistas à discussão e negociação de políticas públicas. A equipe que redigirá o plano analisará o que foi produzido na Conferência e, a partir daí, formulará a proposta que irá ao Congresso Nacional para ser discutida, reformulada e aprovada. Sendo assim, no percurso, as propostas populares podem ser descaracterizadas facilmente ou ignoradas e isso pode gerar grande frustração.

Mantemos, para a análise da abertura do Estado, os aspectos anteriormente elencados: ruptura com racionalidade burocrática e verticalizada, transparência, e incorporação da concepção de gestão democrática às práticas administrativas.

A Conferência de Cultura não contou com texto-base e sim com texto orientador do debate (Conversas com integrantes da equipe). De qualquer forma, a crítica da formulação centralizada do texto que acaba por pautar o debate pode nos fazer perceber traços da racionalidade burocrática e verticalizada. Segundo o coordenador da conferência, a fragilidade do setor cultural era tamanha que sabiam que a pauta que o Ministério lançasse seria aceita pelos 
participantes das instâncias preparatórias (Entrevistado 2). O poder de agendamento da discussão acaba por expressar a capacidade de controle do processo. A ruptura com a racionalidade verticalizada também não existiu na ação de consentimento forçado do regulamento da Conferência.

No âmbito da transparência, não são realizadas ações de acompanhamento da implementação das decisões da Conferência, até pelo caráter consultivo do processo. O Ministério da Cultura continua a trabalhar na articulação do Sistema Nacional de Cultura, fortalecido com o processo de mobilização da Conferência. São realizadas, em especial, ações de esclarecimento e convencimento a respeito da institucionalidade em construção (Entrevistado 2).

A incorporação da concepção de gestão democrática às práticas administrativas tem sido estimulada em ações indutoras pelo Ministério da Cultura. A realização da Conferência Nacional desencadeou processos locais de implantação de secretarias de cultura, conselhos de cultura e debates para formulação de planos municipais de cultura (Entrevistado 2). Esse aspecto não é diretamente relacionado ao canal de participação Conferência, dificultando a análise.

O elemento redefinição dos atores políticos foi observado, no caso da Conferência de Cultura, com o reconhecimento da pluralidade de atores políticos por meio da metodologia que buscou dar conta da complexidade do processo que envolveu participantes com acúmulos distintos sobre a política cultural e da garantia de participação para integrantes do poder público e da sociedade (MINC, 2005b). No evento nacional, no aspecto do reconhecimento mútuo entre os atores envolvidos no processo, as reuniões partidárias durante o evento marcaram disputas que, em alguns momentos, afloraram a desvalorização de setores sociais não vinculados a partidos políticos (Conversas com integrantes da equipe).

O fortalecimento autônomo da sociedade organizada ocorreu, na Conferência de Cultura, pela oportunidade de encontro entre agentes culturais. O Ministério, ao convocar a instância de participação, oportunizou articulações da sociedade civil, como foi o caso da reivindicação de garantia de orçamento para cultura (Conversas com participantes). A questão do possível esvaziamento de movimentos com a incorporação de quadros à estrutura de gestão é 
também explícita na área cultural, tendo em vista que muitos gestores são também agentes culturais (Entrevistado 2).

O reconhecimento do governo como ator no processo também ocorreu com a garantia de participação de gestores públicos. Porém, a confusão entre a representação dos interesses do Estado e as convicções como agente cultural fazem esse aspecto mais tênue na caracterização deste espaço de participação.

No que diz respeito ao espaço para a população não organizada, houve oportunidade de participação nas etapas preparatórias, mas sem ações específicas de incentivo.

\subsection{Limites e possibilidades}

Encerrando a análise das Conferências Nacionais, trataremos dos limites e possibilidades dessas instâncias de participação a partir do quadro comparativo entre as Conferências Nacionais de Meio Ambiente e a Conferência Nacional de Cultura com base nos elementos caracterizadores do modo petista de governar.

\begin{tabular}{|c|c|c|}
\hline \multirow{2}{*}{ 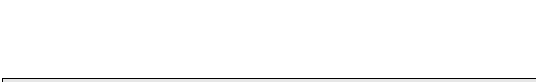 } & \multirow{2}{*}{ Meio Ambiente } & \multirow{2}{*}{ Cultura } \\
\hline & & \\
\hline \multicolumn{3}{|l|}{$\begin{array}{l}\text { 1. Criação de novas esferas } \\
\text { públicas democráticas }\end{array}$} \\
\hline 1.1. Auto-regulação & $\begin{array}{l}\text { Aprovação de regimento interno e } \\
\text { institucionalização do processo. }\end{array}$ & Regimento interno imposto \\
\hline 1.2. Explicitação de interesses & Metodologia tradicional & Metodologia diferenciada \\
\hline 1.3. Interação Estado-Sociedade & Caráter deliberativo & Caráter consultivo \\
\hline \multicolumn{3}{|l|}{ 2. Abertura do Estado } \\
\hline 2.1. Racionalidade burocrática & Texto-base para emendas & Texto orientador como pauta \\
\hline 2.2. Transparência & Implementação monitorada & Ações de esclarecimento \\
\hline 2.3. Práticas administrativas & Comissões tripartites & Indução de processos locais \\
\hline \multicolumn{3}{|l|}{ 3. Redefinição de atores políticos } \\
\hline 3.1. Pluralidade & Cotas para participação & Cotas para participação \\
\hline 3.2. Autonomia da sociedade & Instância de legitimação & Encontro de agentes culturais \\
\hline 3.3. População não-organizada & Não houve incentivo & Não houve incentivo \\
\hline 3.4. Governo como ator & Participação de gestores & Participação de gestores \\
\hline
\end{tabular}


Ao compararmos as experiências acima descritas e analisadas, fica evidente que a maior diferenciação diz respeito à natureza ou ao caráter dessas esferas públicas democráticas. A Conferência Nacional de Cultura assumiu o caráter consultivo, enquanto as duas edições da Conferência Nacional de Meio Ambiente tiveram caráter deliberativo. A natureza da interação entre Estado e Sociedade para discussão e negociação de políticas públicas, no âmbito das Conferências, faz emergir o dilema entre consulta e deliberação, debate já existente no início das gestões petistas, como indicado na seção 1.2 deste trabalho. Embora a visão de consulta limite a partilha de poder e a interação plena no canal de participação, assumir o caráter consultivo é honesto diante da realidade da gestão pública. Afinal, o caráter deliberativo não garante a execução das propostas aprovadas em uma Conferência. É sabido que, com recursos limitados, a definição de prioridades diante das deliberações acontecerá com base nas convicções dos gestores responsáveis pela ação. Nesse sentido, a lógica de priorização com a participação da população, realizada na Conferência de Cultura, contribui com a efetividade das decisões do espaço de participação. Vale a experiência, ainda não realizada, de instituir espaço de participação com caráter deliberativo que trabalhe com a lógica da priorização.

Na maneira como se constituíram as duas Conferências também percebemos limites e possibilidades dessas instâncias de participação. A inovação metodológica da Conferência de Cultura em relação à Conferência de Meio Ambiente, nos elementos de priorização e interação, aponta para uma forma diferenciada de explicitar os interesses e conflitos. As formas como se estruturaram as negociações e decisões nas Conferências revelam concepções distintas de participação. A Conferência de Meio Ambiente valorizou as formas de atuação já consagradas nas militâncias sindicais e de movimentos sociais, a saber: as plenárias em que "minorias hábeis" disputam espaço de fala e vencem a maioria pelo cansaço. Essa forma de gerir o espaço é facilitada pela cultura de participação da maioria dos participantes, além de explicitar mais fortemente os conflitos, mas acaba sendo ineficiente ao demandar tempo que inexiste em encontros do porte de uma Conferência. A Conferência de Cultura ousou romper com a cultura política da militância e apoiou-se em técnicas de interação polifônicas, como o momento interativo em que centenas de pessoas conversaram ao mesmo tempo e contribuíram na qualificação do trabalho dos grupos. A lógica da priorização ajudou a formulação de propostas 
mais fortes e consensuadas, mas inibiou expressões de conflitos latentes em plenárias. O desenho de metodologias de participação condizentes com as realidades nas quais serão implementadas é fundamental, portanto não há modelos únicos a serem seguidos. No entanto, há que existir inovação para que as esferas públicas criadas sejam efetivadas.

Foi também explícita a diferença entre as duas Conferências no que diz respeito à auto-regulação. Na Conferência de Cultura, não houve, como nas Conferências de Meio Ambiente, espaço para discussão e aprovação do regimento interno. Essa estratégia limita o canal de participação, pois reforça a racionalidade burocrática e verticalizada do Estado. A institucionalização da Conferência de Meio Ambiente como instância do Sistema Nacional de Meio Ambiente indica fortalecimento do espaço de participação. Cabe, pois, avançar na institucionalização dos canais de participação, tendo como princípio a auto-regulação.

No quesito abertura do Estado também há forte limite com o poder de agenda. Em ambos os casos, a ruptura com a racionalidade burocrática e verticalizada do Estado não ocorreu, pois os documentos orientadores do debate foram formulados pelos Ministérios sem a participação de representantes da sociedade. Na Conferência de Meio Ambiente a metodologia do processo com texto-base a ser emendado pelos participante revela inclusive tendência à legitimação das ações do governo quando as teses a serem debatidas são as políticas do executivo federal. Uma possibilidade é o envolvimento dos diversos atores na formulação da pauta a ser debatida, pois a construção coletiva da agenda de debate amplia a legitimidade dos resultados.

Pelos distintos processos, a transparência teve formas diferenciadas de expressão. Na Conferência de Meio Ambiente foram formados grupos de trabalho para o acompanhamento da implementação das deliberações. Na Conferência de Cultura não houve acompanhamento de implementação, pois as propostas seguiram caminhos diferentes da área ambiental. Radicalizar a transparência em todas as etapas do processo parece ser limite e desafio aos canais de participação. A sistematização contínua dos resultados deve ser adotada como princípio e aliada com uma boa estratégia de comunicação que efetive a transparência como requisito da existência de controle social. 
As práticas adotadas pelos dois Ministérios analisadas sobre os outros aspectos se assemelham. Cabe ressaltar a questão da integração das ações governamentais permitindo a efetivação das ações definidas em instâncias de participação. A possível dificuldade, apontada na seção 4.2, limitou a eficácia das ações de participação em decorrência da separação do órgão de articulação com a sociedade - Secretaria-Geral da Presidência da República, do órgão de integração das ações governamentais - Casa Civil. O limite da integração foi reconhecido pelo próprio governo, por ocasião da reunião com Coordenadores de Conferências Nacionais (Entrevistado 3). Isso aponta para a necessidade de superação do isolamento das ações de participação em relação ao conjunto da estrutura administrativa, além da urgência de repensar a estrutura de gestão para que dê conta de aliar articulação com sociedade e integração de ações governamentais. A experiência de Porto Alegre com o Orçamento Participativo como espaço central de decisões que impulsionou as secretarias municipais a coordenar ações (ABERS, 2000), poderia inspirar estrutura, em nível federal, para articulação inovadora entre políticas setoriais.

Encerramos essa análise de espaços de participação no governo Lula com a afirmação de que as experiências locais de participação devem ser ainda mais valorizadas. Foi a partir delas que o PT concebeu a sua forma de gestão democrática e, após implementar ações em nível federal, deve resgatar os aprendizados da gestão local. São mecanismos locais que podem aproximar a política da população não-organizada e provocar efetivas transformações nas práticas administrativas visando a orientação do Estado pela Sociedade. Vejamos as possíveis conclusões desta pesquisa. 


\section{CONCLUSÕES}

Este trabalho teve como intenção lançar um olhar sobre o modo petista de governar, especificamente no que diz respeito à participação social. A intenção de pesquisa foi perceber como o governo Lula aproveitou as experiências locais de participação local. Ao final da análise, percebemos que as experiências inovadoras de canais institucionais de participação social empreendidas nos governos locais não foram incorporadas plenamente em nível federal, explicitando limites e possibilidades das instâncias nacionais de participação.

Embora exista a percepção da "multiplicação dos espaços de interlocução, sem que houvesse (e haja) política de governo, sem falar de Estado, de fortalecimento do sistema descentralizado e participativo, muito menos de ampliação dos processos democráticos" (MORONI, 2005:15), percebemos a relevância das ações de governo empreendidas no sentido de ampliar a participação social. Além dos resultados, ainda pouco significativos, na implementação de gestão democrática em nível nacional, é fundamental ressaltar o papel do governo federal como indutor dos outros níveis de governo. Desta forma, os esforços para a criação de novas esferas públicas democráticas, a abertura do Estado e a redefinição de atores políticos, marcarão outras gestões federais.

Reconhecemos o valor das diversas iniciativas para a consolidação de práticas democráticas na gestão pública e não pactuamos com a opinião que diz que a participação "ficou reduzida à estratégia de governabilidade e a um faz-de-conta" (MORONI, 2005:15). As iniciativas aqui descritas evidenciam a democratização do processo. Embora haja muito o que avançar, em especial, na capacidade do Estado em responder às demandas sociais, o que falta é articular a "democratização do processo com a eficácia dos resultados" (TATAGIBA, 2002:47).

Já apontamos limites e possibilidades de instâncias de participação empreendidas. Além disso, a complexidade das ações nacionais demonstram a necessidade de incremento qualitativo e de avanço em alguns pontos que aqui delinearemos antes de apontarmos 
possíveis conclusões para a constatação de baixo aproveitamento em nível nacional das experiências locais do modo petista de governar.

Com mais de cinco mil deliberações advindas das 32 Conferências, a questão que se impõe é como dirimir as propostas contraditórias e levar à frente as ações requeridas pela população nas instâncias de participação (Entrevistado 3). Vinculada à capacidade de implementação das deliberações está a necessidade de avançar na participação nos instrumentos de planejamento e nas decisões de política econômica, inclusive com a integração entre decisões das Conferências e elaboração do PPA (Entrevistado 1; CAMURÇA, 2006; MORONI, 2005; Entrevistado 3). Isso nos faz pensar que o elemento sobre o que se faz política, indicado nas formas de resignificação da política (DAGNINO, 1998:78), deve ser agregado em futuras análises de gestões democráticas.

No nível da gestão dos canais de participação já existentes, além de ampliá-los, é necessária a qualificação do processo, inclusive com clareza sobre as consequiências da opção pelo caráter consultivo ou deliberativo das instâncias. Qualificação que passa pela revisão das metodologias, aperfeiçoando os instrumentos democráticos (Entrevistado 3), bem como a alteração de princípios que levem à co-responsabilização do Estado e da Sociedade com o processo decisório (Entrevistada 4). Para que esses avanços sejam implementados, a coordenação mais presente por parte da Secretaria-Geral da Presidência da República far-se-á necessária.

Algumas justificativas podem ser apontadas para o não aproveitamento completo dos aprendizados e práticas das experiências locais. Entre elas, a política de alianças que deu base de sustentação ao governo também trouxe para a mesma gestão visões diferenciadas sobre participação social. Existiram "ministros e dirigentes mais afeiçoados à participação e outros menos" (Entrevistado 3).

Ligada a essa pluralidade de percepções internas a respeito da participação, outra possível conclusão é a baixa integração entre órgãos do governo federal, bem como entre esses e órgãos municipais e estaduais. A fragilidade do pacto federativo é explicitada, no momento em que uma instância de participação federal delibera sobre questões de responsabilidades de municípios e estados (Entrevistado 3). A baixa integração entre órgãos 
federais gera a não implementação de deliberações cuja responsabilidade transcende a competência do ministério que implementa o canal de participação (Entrevistado 1; CAMURÇA, 2006; Entrevistado 2; Entrevistado 3).

Ademais, a complexidade de lidar com a gestão federal em um país com diferenças abismais entre regiões, estados e municípios, fez emergir os limites dos mecanismos de participação desenvolvidos para instâncias locais. O "choque com a realidade" (PONTUAL \& SILVA, 1999:63) que as gestões petistas municipais enfrentaram na implementação dos ideais de participação parece também ter ocorrido quando o Partido dos Trabalhadores assumiu o governo federal. Alguns gestores pareciam acreditar que seria simples implementar a participação em nível federal (Entrevistado 3), mas observamos entraves e ineficiência em alguns mecanismos desenvolvidos em nível nacional a partir das experiências locais.

Mesmo não sendo possível transpor os instrumentos já desenvolvidos em municípios geridos pelo PT, e enfrentando as dificuldades acima mencionadas, alguns gestores conseguiram aproveitar suas experiências e levar ao governo federal cultura petista de gestão, ou o modo petista de governar (Entrevistado 2). Foram diversas as experiências de participação, explicitadas nas comparações feitas entre as duas edições da Conferência Nacional de Meio Ambiente e a Conferência Nacional de Cultura. No entanto, observa-se que o modo petista de governar não conseguiu a eficiência necessária quando empreendido em nível federal.

Por fim, cabe menção a possíveis discursos que fundamentam visões de participação implementadas no modo petista de governar. A participação justifica-se em alguns elementos de discurso que podem ser incorporados às práticas de gestão democrática: a participação qualifica as ações governamentais, quando adequa a visão do projeto vitorioso nas eleições às demandas reais da sociedade; a participação aflora contradições e conflitos sociais que podem ser resolvidos de forma democrática, inclusive permitindo consensos; a participação divide o poder entre Estado e Sociedade; a participação fortalece articulação e identidade de setores sociais; e a participação desencadeia processos de co-gestão locais (Entrevistado 1; Entrevistado 2; Entrevistado 3; Entrevistada 4). 
Reconhecemos, nas práticas e discursos analisados nesse trabalho, a necessidade de transcender a caracterização do modo de governar de um partido, pois visualizamos nos resultados da pesquisa realizada elementos essenciais à concepção de gestão pública democrática. A partir desses elementos temos interesse, em nível mais profundo de estudo, de desenvolver instrumentos analíticos capazes de avaliar práticas de gestão em canais de institucionais que tornem realidade a utopia da participação social que mobiliza a criatividade e as habilidades das pessoas visando a efetividade das ações coletivas, o desenvolvimento dos potenciais dos indivíduos e a sustentabilidade das comunidades. 


\section{REFERÊNCIAS}

\section{BIBLIOGRAFIA}

ABERS, Rebecca. Inventing Local Democracy: Neighborhood Organizing and Participatory Policy-making in Porto Alegre. Colorado: Lynne Rienner Publishers, 2000. Cap 4.

ASSEMBlÉIA POPUlar. Carta da Assembléia Popular ao Presidente Lula e ao Povo Brasileiro. Brasília, 2005. [on line] Disponível em: <www.assembleiapopular.com.br/ assembleianoticia20.htm> Acesso em: 16/06/2006

AZEVEDO, Ricardo de. Uma varinha de condão? Teoria e Debate. [online] Set. 1988, $\mathrm{n}^{\circ} 4$, Disponível em: <www.fpabramo.org.br/td/td04/td4_opiniao.htm> Acesso em 26/05/2006.

BITTAR, Jorge. (org) O modo petista de governar. Caderno especial de Teoria \& Debate. São Paulo: Secretaria de Assuntos Institucionais - PT, 1992.

CAMURÇA, Silvia Maria Sampaio. Políticas para as mulheres. Teoria e Debate. $\mathrm{n}^{\circ} 66$ Abril/Maio/Junho 2006.

CREMONESE, Dejalma. Eleições 2004: Uma análise do desempenho petista. Revista Espaço Acadêmico. [online] Dez, 2004. $\mathrm{n}^{\mathbf{0}}$ 43. Disponível em: <www.espacoacademico.com.br/043/43ccremonese.htm> Acesso em 30/05/2006.

DAGNINO, Evelina. Cultura, Cidadania e Democracia: A transformação dos discursos e práticas da esquerda brasileira. in Cultura e Política nos Movimentos Sociais Latino Americanos: Novas Leituras, (Sônia Alvarez, Evelina Dagnino e Arturo Escobar, orgs.) Belo Horizonte: Editora da UFMG, 1998. pp 61-102

DANIEL, Celso. A gestão local no limiar do novo milênio. in Governo e cidadania - Balanço e reflexões sobre o modo petista de governar. São Paulo: Fundação Perseu Abramo, 1999.

DANIEL, Celso. Como viabilizar a participação popular no governo municipal Teoria e Debate. [online] Mar. 1988, $\mathrm{n}^{\circ}$ 2. Disponível em: <www.fpabramo.org.br/td/td02/ td02_sociedade3.htm> Acesso em 26/05/2006.

DELGADO, Nelson. \& LIMONCIC, Flávio. Reflexões preliminares sobre espaços públicos de participação no governo Lula. in Democracia Viva $\mathrm{n}^{\mathbf{0}} 23$, 2005. Disponível em: <www.ibase.br/pubibase/media/dv23_opiniaolbase_ibasenet_final.pdf> Acesso em 20/03/2006 
FERNANDES, Florestan. O PT - Dilema das eleições municipais. Folha da Manhã, 9 de junho de 1988. Disponível em: <http://almanaque.folha.uol.com.br/florestan14.htm> Acesso em 26/05/2006.

FREIRE, Paulo. A construção de uma nova cultura política. in Poder local, Participação Popular, Construção da Cidadania. São Paulo: Fórum Nacional de Participação Popular nas Administrações Populares, 1994.

GENRO, Tarso. Utopia Possível. Porto Alegre: Artes e Ofícios, 1995. $2^{\text {a }}$ edição

GOHN, Maria da Glória M. Conselhos populares e participação popular. Revista Serviço Social e Sociedade. no 34 São Paulo: Cortez, 1990.

HOCHMAN, G. Reformas, instituições e políticas de saúde no Brasil (1930-1945) Educar. n. 25 Curitiba: Editora UFPR, 2005.

KECK, Margaret. PT: A Lógica da Diferença. Tradução Maria Lucia Montes. São Paulo: Ática, 1991.

LACERDA, Alan Daniel Freire de. O PT e a Unidade Partidária como Problema. in Dados. 2002, vol.45, no.1, p.39-76. [online] Disponível em: <www.scielo.br/scielo.php?script= sci_arttext\&pid=S0011 -52582002000100002\&lng=en\&nrm=iso> Acesso em 01/07/2006.

LAERTE, Adão Iturrusgarai. Ilustrações in Onde está a Democracia? Belo Horizonte: Editora UFMG, 2002.

MINC - Ministério da Cultura. Relatório premiliminar da I Conferência Nacional de Cultura. 2005a. [on line] Disponível em <www.cultura.gov.br/upload/relatorio_nacional_1135346095.pdf> Acesso em 02/07/2006.

Cultura. 2005b.

Manual do Participante da I Conferência Nacional de

MMA - Ministério do Meio Ambiente. Relatório da I Conferência Nacional do Meio Ambiente. Documento interno, 2004.

Brasília: MMA, 2005.

Ações do MMA para as deliberações da I CNMA.

Resultado da Pesquisa com Participantes da II Conferência Nacional do Meio Ambiente. Brasília: MMA, 2006 .

Ambiente. Brasília: MMA, 2006b.

Deliberações. II Conferência Nacional do Meio 
MAPAS - Monitoramento Ativo da Participação da Sociedade. A experiência do Projeto Mapas de monitoramento político de iniciativas de participação do governo Lula. Ibase. [online] Disponível em: <www.ibase.br/pubibase/media/experiencia.zip> Acesso em 06/03/2006.

MARICATO, Ermínia. \& SANTOS JÚNIOR, Orlando Alves dos. Uma política urbana participativa. Teoria e Debate. $\mathrm{n}^{\circ} 66$ Abril/Maio/Junho 2006.

MENEZES, Francisco. Segurança Alimentar e Nutricional Teoria e Debate. $\mathrm{n}^{\mathbf{o}} 66$ Abril/Maio/Junho 2006.

MESQUISTA JÚNIOR, Geraldo \& NOGUEIRA, Octaciano. Sistemas Democráticos - teoria da democracia. Unidade V do curso Política e Cidadania. Brasília: Senado Federal, 2005.

MORONI, José. Participamos, e daí? in Observatório da Cidadania - Textos para Debate. Novembro de 2005. [on line] Disponível em: <www.ibase.br/pubibase/media/ Participacao_Moroni.pdf> Acesso em 25/04/2006.

PINTO, Valeska Peres. A vitrine do ABC. Teoria e Debate. [online] Jun. 1988, nº 3. Disponível em: <www.fpabramo.org.br/td/td03/td3_opiniao.htm> Acesso em 26/05/2006.

PONTUAL, Pedro \& SILVA, Carla Cecília R. A. Participação popular nos governos petistas. in Governo e cidadania - Balanço e reflexões sobre o modo petista de governar. São Paulo: Fundação Perseu Abramo, 1999.

PT, Partido dos Trabalhadores. Resoluções de Encontros e Congressos. São Paulo: Fundação Perseu Abramo, 1998.

Concepção e Diretrizes do Programa de Governo do PT para

o Brasil 2002, 2002a [online] Disponível em: <www.lula.org.br/assets/diretrizes.pdf> Acesso em $24 / 02 / 2006$.

2002b [online] Disponível em: <www.pt.org.br/site/assets/programadegoverno.pdf> Acesso em $23 / 02 / 2006$.

- Carta ao povo Brasileiro, 2002c [online] Disponível em: <www.lula.org.br/assets/carta_ao_povo_brasileiro.pdf> Acesso em 23/02/2006.

Programa de Governo 2002 Coligação Lula Presidente Caderno Temático: Meio Ambiente e Qualidade de Vida. 2002d [online] Disponível em: <www.pt.org.br/site/assets/cadernomeioambiente.pdf> Acesso em 20/06/2006.

RODRIGUES, Edmilson. Modos petistas de governar. in Governo e cidadania - Balanço e reflexões sobre o modo petista de governar. São Paulo: Fundação Perseu Abramo, 1999.

ROMBAUER, Eduardo. \& SOUZA, Clóvis Henrique Leite de. Metodologia da $\mathbf{1}^{\text {a }}$ Conferência Nacional de Cultura: ampliação e qualificação da participação social na elaboração de 
política públicas. 2006. Texto pessoal a ser publicado nos anais da I Conferência Nacional de Cultura.

SAMUELS, David. As bases do petismo. Opinião Pública. [online]. Out. 2004, vol. 10, $\mathrm{n}^{\circ}$ 2, p.221-241. Disponível em: <www.scielo.br/scielo.php?script=sci_arttext\&pid=S0104$62762004000200002 \& \operatorname{lng}=e n \& n r m=i s o>$. Acesso em 20/05/2006.

SECRETARIA-GERAL DA PRESIDÊNCIA DA REPÚBLICA. Informativo Participação Social. Dezembro de 2005.

Social. Abril de 2006.

Informativo Participação

SILVA, Rodney da. Controle da Administração Pública no Direito Comparado: ombudsman, defensor do povo, provedor da justiça. in Revista CESUC, ano IV, $\mathrm{n}^{\circ}$ 7, 2002. Disponível em <www.cesuc.br/revista/ed-2/CONTROLE DA ADMINISTRACAO.pdf> Acesso em 16/06/2006.

SIMÕES, Júlio Assis. O dilema da participação popular: a etnografia de um caso. São Paulo: ANPOCS - Marco Zero, 1992.

SNAI, Secretaria Nacional de Assuntos Institucionais - PT. Evolução dos Governos e Mandatos do PT. [online] Dez, 2002. Disponível em <www.pt.org.br/site/upload_secretarias/170-2003_013-45-40_historico_institucional202002.ppt> Acesso em 30/05/2006.

SOLER, Salvador. Experiências democráticas de participação nas prefeituras. in Poder local, Participação Popular, Construção da Cidadania. São Paulo: Fórum Nacional de Participação Popular nas Administrações Populares, 1994.

SOUZA, Ubiratan. Orçamento participativo, do município ao estado. in Governo e cidadania Balanço e reflexões sobre o modo petista de governar. São Paulo: Fundação Perseu Abramo, 1999.

TATAGIBA, Luciana. Os Conselhos Gestores e a Democratização das Políticas Públicas no Brasil. in Sociedade Civil e espaços públicos no Brasil. São Paulo: Paz e Terra, 2002.

TEIXEIRA, Ana Claudia Chaves. \& TATAGIBA, Luciana. Movimentos sociais e sistema político: os desafios da participação. São Paulo: Instituto Pólis/PUC-SP, 2005.

TREVAS, Vicente. O Partido dos Trabalhadores e suas experiências de governo. in Governo e cidadania - Balanço e reflexões sobre o modo petista de governar. São Paulo: Fundação Perseu Abramo, 1999. 


\section{ENTREVISTAS}

Entrevistado 1 - Coordenador da II Conferência Nacional de Meio Ambiente. Entrevista realizada em 26/06/2006.

Entrevistado 2 - Coordenador da I Conferência Nacional de Cultura. Entrevista realizada em $16 / 06 / 2006$.

Entrevistado 3 - Assessor da Secretaria-Geral da Presidência da República - Secretaria Nacional de Articulação Social. Entrevista realizada em 22/06/2006

Entrevistada 4 - Coordenadora da I Conferência Nacional de Meio Ambiente e das duas edições Infanto-Juvenis. Entrevista realizada em 10/06/2006. 